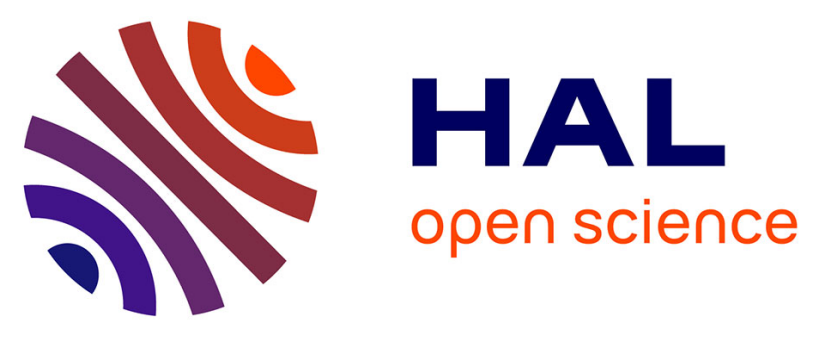

\title{
Chemoenzymatic synthesis of arabinomannan (AM) glycoconjugates as potential vaccines for tuberculosis
}

Zhihao Li, Teodora Bavaro, Sara Tengattini, Roberta Bernardini, Maurizio

Mattei, Francesca Annunziata, Richard B Cole, Changping Zheng, Matthieu

Sollogoub, Lucia Tamborini, et al.

\section{To cite this version:}

Zhihao Li, Teodora Bavaro, Sara Tengattini, Roberta Bernardini, Maurizio Mattei, et al.. Chemoenzymatic synthesis of arabinomannan (AM) glycoconjugates as potential vaccines for tuberculosis. European Journal of Medicinal Chemistry, 2020, 204, pp.112578. 10.1016/j.ejmech.2020.112578 . hal-02926443

\section{HAL Id: hal-02926443 \\ https://hal.sorbonne-universite.fr/hal-02926443}

Submitted on 31 Aug 2020

HAL is a multi-disciplinary open access archive for the deposit and dissemination of scientific research documents, whether they are published or not. The documents may come from teaching and research institutions in France or abroad, or from public or private research centers.
L'archive ouverte pluridisciplinaire HAL, est destinée au dépôt et à la diffusion de documents scientifiques de niveau recherche, publiés ou non, émanant des établissements d'enseignement et de recherche français ou étrangers, des laboratoires publics ou privés. 


\title{
Chemoenzymatic Synthesis of Arabinomannan (AM) Glycoconjugates as Potential Vaccines for Tuberculosis
}

\author{
Zhihao Li, ${ }^{a}$ Teodora Bavaro, ${ }^{\mathrm{b}}$ Sara Tengattini, ${ }^{\mathrm{b}}$ Roberta Bernardini, ${ }^{\mathrm{c}}$ Maurizio \\ Mattei, ${ }^{\mathrm{c}, \mathrm{d}}$ Francesca Annunziata, ${ }^{\mathrm{e}}$ Richard B. Cole, ${ }^{\mathrm{a}}$ Changping Zheng, ${ }^{\mathrm{a}}$ Matthieu \\ Sollogoub, ${ }^{\mathrm{a}}$ Lucia Tamborini, ${ }^{\mathrm{e}}$ Marco Terreni, ${ }^{\mathrm{b} *}$ Yongmin Zhang. ${ }^{\mathrm{a}, \mathrm{f}, *}$
}

\begin{abstract}
${ }^{a}$ Sorbonne Université, CNRS, Institut Parisien de Chimie Moléculaire, UMR 8232, 4 Place Jussieu, 75005 Paris, France. ${ }^{b}$ Drug Sciences Department, University of Pavia, Viale Taramelli 12, 27100 Pavia, Italy. ${ }^{c}$ Italy Centro Servizi Interdipartimentale - STA, University of Rome "Tor Vergata", Rome, Italy. "Department of Biology, University of Rome "Tor Vergata”, Rome, Italy. ${ }^{e}$ Department of Pharmaceutical Sciences, University of Milan, via Mangiagalli 25, 20133 Milan, Italy. ${ }^{f}$ Key Laboratory of Tropical Medicinal Resource Chemistry of Ministry of Education, College of Chemistry \& Chemical Engineering, Hainan Normal University, Haikou 571158, China.
\end{abstract}

\begin{abstract}
Mycobacteria infection resulting in tuberculosis (TB) is one of the top ten leading causes of death worldwide in 2018, and lipoarabinomannan (LAM) has been confirmed to be the most important antigenic oligosaccharide on the TB cell surface. In this study, a convenient synthetic method has been developed for synthesizing three branched oligosaccharides derived from LAM, in which a core building block was prepared by enzymatic hydrolysis in flow chemistry with excellent yield. After a series of steps of glycosylations, the obtained oligosaccharides were conjugated with recombinant human serum albumin (rHSA) and the ex-vivo ELISA tests were performed using serum obtained from several TB-infected patients, in order to evaluate the affinity of the glycoconjugate products for the human LAM-antibodies. The evaluation results are positive, especially compound $\mathbf{2 1}$ that exhibited excellent activity which could be considered as a lead compound for the future development of a new glycoconjugated vaccine against TB.
\end{abstract}

Keywords: lipoarabinomannan; glycoconjugate; chemoenzymatic synthesis; tuberculosis; vaccine

\section{Introduction}


Ranking above HIV in 2018, around 1.5 million people died from tuberculosis (TB), which is among the top 10 causes of death. Moreover, $25 \%$ of the world's population has latent TB, meaning civilians have been infected by TB bacteria without showing signs of illness. Due to the serious situation, ending the TB epidemic becomes one of the health targets of the Sustainable Development Goals by 2030[1]. Although tuberculosis is curable by administering medicine, the efficacy of drugs is limited by multiple drug resistance (MDR) and extensively-drug resistance (XDR)[2]. As an example, it is estimated that during 2018 there were 484000 new cases resistant to the most effective first-line drug rifampicin, leading to vaccination as still being the ideal method of fighting against TB. However, BCG (Bacillus Calmette-Guérin) is the only licensed vaccine against $\mathrm{TB}$ and it is only effective for children[3]. Thus, there remains an urgency to develop novel vaccines for TB prevention.

Carbohydrates are commonly found in nature as one of most complicated and diverse classes of biomolecules. They play important roles in fundamental biological processes with the outcome that many pharmaceuticals and vaccines use them as building blocks[4], and today glycoconjugate vaccines are being regarded as one of the safest and most effective anti-infective vaccines being manufactured in the last few decades[5, 6]. Commercial glycoconjugate vaccines are commonly obtained from antigenic sugar isolated from pathogens[4, 7, 8]. For Mycobacterium tuberculosis (M.TB) the most important sugar-antigen is the glycolipid lipoarabinomannan (LAM) that is also common to other Mycobacterium species.

Now the complex structure of the M.TB membrane oligosaccharides has been well established[9]. In the case of LAM, the arabinomannane (AM) is the antigenic structure composed by an internal mannan backbone, made of $\alpha(1 \rightarrow 6)$ and $\alpha(1 \rightarrow 2)$ D-mannose units and covered by a long and branched arabinan domain. The non-reducing terminus of AM is composed by branched motifs including D-Ara- $\beta(1 \rightarrow 2)$ disaccharide units linked with D-arabinose by $\alpha(1 \rightarrow 5)$ and $\alpha(1 \rightarrow 3)$ bonds (Figure $1 \mathbf{A})$. This motif can also be end capped with D-mannose or D-Man- $\alpha(1 \rightarrow 2)$ D-Man units in LAM[10]. Branched motifs of D-arabinose by $\alpha(1 \rightarrow 5)$ and $\alpha(1 \rightarrow 3)$ bonds are also involved in different parts of the arabinan domain of LAM (Figure 1 B). Moreover, these D-Ara motifs of LAM are common with arabinogalactane (AG), another important oligosaccharide in M.TB membrane which is crucial for cell growth, viability, and virulence[11, 12]. 

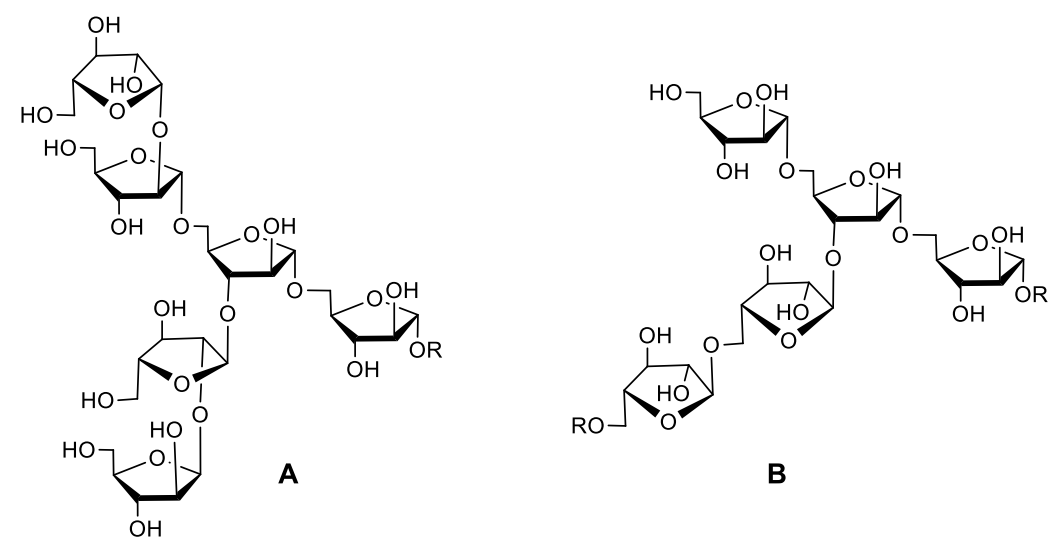

Figure 1. Structure of the branched motifs in AM

Since different glycoforms of LAM exposed outside the M.TB membrane were proven to stimulate the production of specific antibodies[13] and this antigen is one of the most important in the BCG vaccine, the conjugation of the AM part with protein has attracted the interests of many researchers and has been proposed as a strategy for the development of new and efficient TB-vaccines $[14,15]$ targeting the LAM antigen, with the advantage that these products could be active against different species of virulent mycobacteria in humans (such as Mycobacterium avium Spp.). Moreover, for the complexity of LAM structure, scientists also studied different types of synthetic AM-analogues and interestingly these analogues became antigenic after conjugating with suitable carrier proteins or lipids[16, 17]. However, until now there is no evidence to show which are the epitopes for this immunological activity. Thus, more fundamental study of AM based vaccine is crucial for the development of efficient sub-unit glycoconjugated vaccines.

In carbohydrate chemistry, the synthesis of oligosaccharides can be strongly limited by the complex chemical procedures involving protection/deprotection strategies by different protecting groups. As one of the most widely used protecting groups, acetyl is widely used in sugar chemistry and different chemical approaches have been reported to deprotect it. Compared to the chemical procedure, biocatalytic deacetylation strategies can selectively deprotect acetyl groups in peracetylated sugars in the desired position, using mild condition and aqueous medium $[18,19]$. Moreover, the development of flow chemistry using immobilized enzyme on packed bed reactors provides wider applications in material discovery, future medicine and compound synthesis[20, 21], which saves time and labor to a significant degree. In addition, for the development of glycoconjugated vaccines, the selection of an adequate chemical linker in the anomeric sugar for 
protein glycosylation should be considered and the synthetic strategy designed accordingly[7, 22, 23].

In the present work, acetyl was used as the only protecting group to avoid the redundant procedures and enzymatic regioselective hydrolysis was conducted to furnish arabinose building blocks with free hydroxy groups in one or two desired positions starting from peracetylated arabinose thioglycosides. Furthermore, in order to improve the performances of the enzymatic reactions, the use of flow-based bioreactors has been also considered. After the required steps of glycosylations, the motif containing D-arabinose branched with $\alpha(1 \rightarrow 5)$ and $\alpha(1 \rightarrow 3)$ D-Ara and some analogues were prepared considering the combination of different arabinose and mannose units, and then glycosylated with a mannose building block possessing a terminal thiocyanomethyl group at the anomeric position[24]. In fact, after one-pot deprotection and activation of the anomeric linker, the glycans obtained were combined with recombinant human serum albumin (rHSA) protein. Finally, the three obtained glycoconjugates (in Figure 2) were submitted to biological evaluation by ex-vivo tests performed on serum obtained from several infected patients in order to evaluate their affinity for the human polyclonal antibodies against TB.

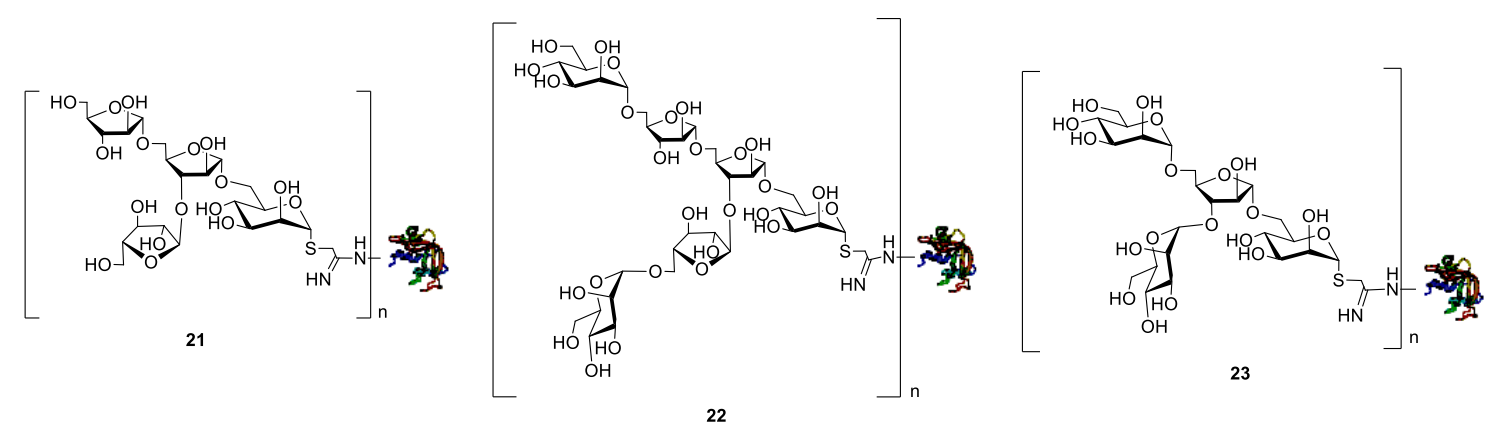

Figure 2. Glyconjugated products as AM analogues

\section{Results and discussion}

\subsection{Synthesis of the oligosaccharide}




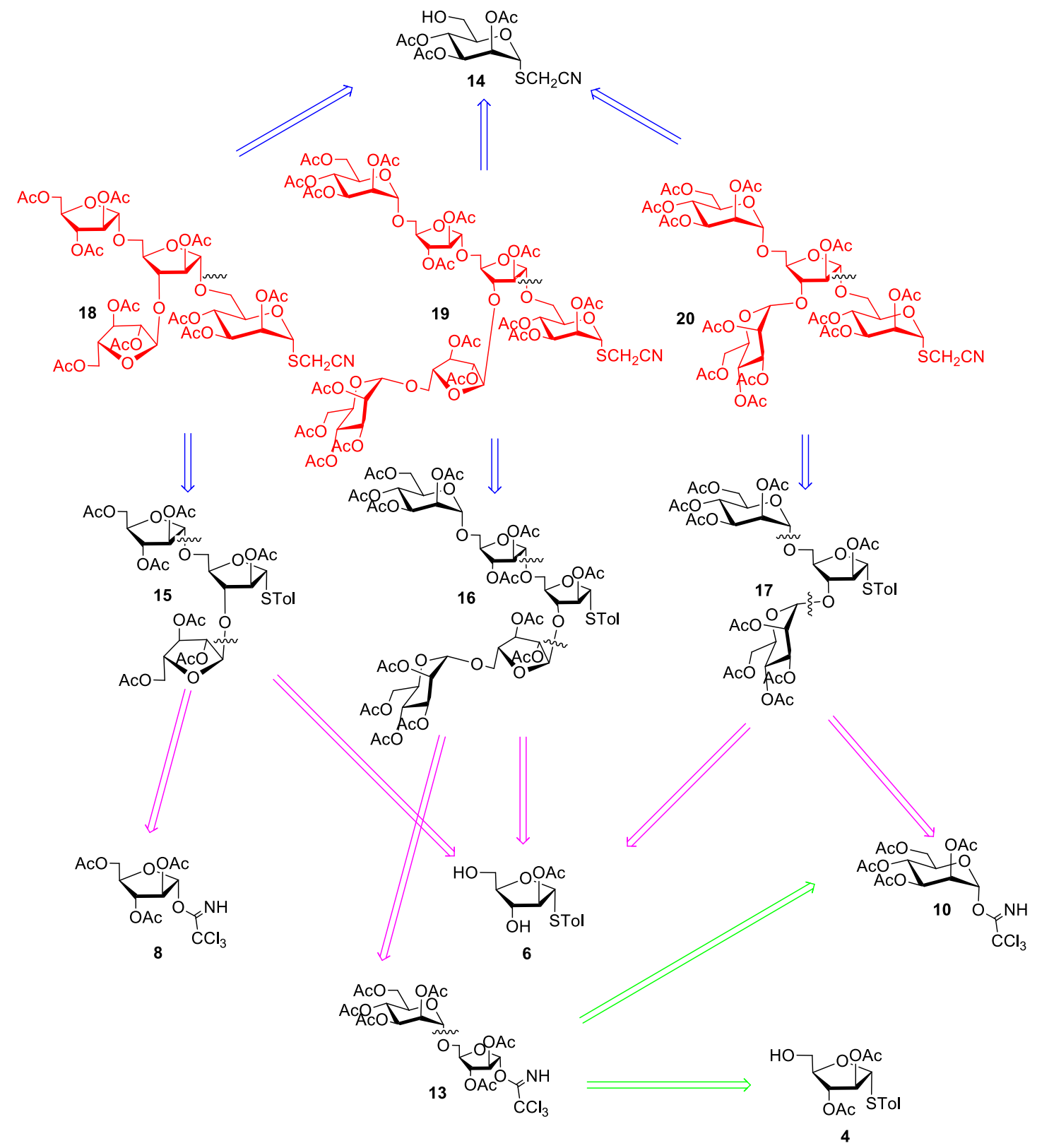

Figure 3. Retrosynthetic analysis for protected AM compounds 18, 19 and 20.

For the synthesis of three acetylated oligosaccharides, intermediates needed are shown in Figure 3 based on the retrosynthetic analysis. First, synthesis of tetrasaccharide $\mathbf{1 8}$ would start with trisaccharide $\mathbf{1 5}$ and monosaccharide 14, while the trisaccharide $\mathbf{1 5}$ is constructed from monosaccharides 6 and 8 . Then for compound 19, using the same monosaccharide 14, a pentasaccharide 16 would be used which can be constructed by disaccharide 13 and monosaccharide 6, where $\mathbf{1 3}$ is synthesized from the two monosaccharides $\mathbf{4}$ and 10. Finally, trisaccharide 17 and monosaccharide 14 are required for preparing 20, in which building block 17 is constructed by compound $\mathbf{6}$ and $\mathbf{1 0}$. 


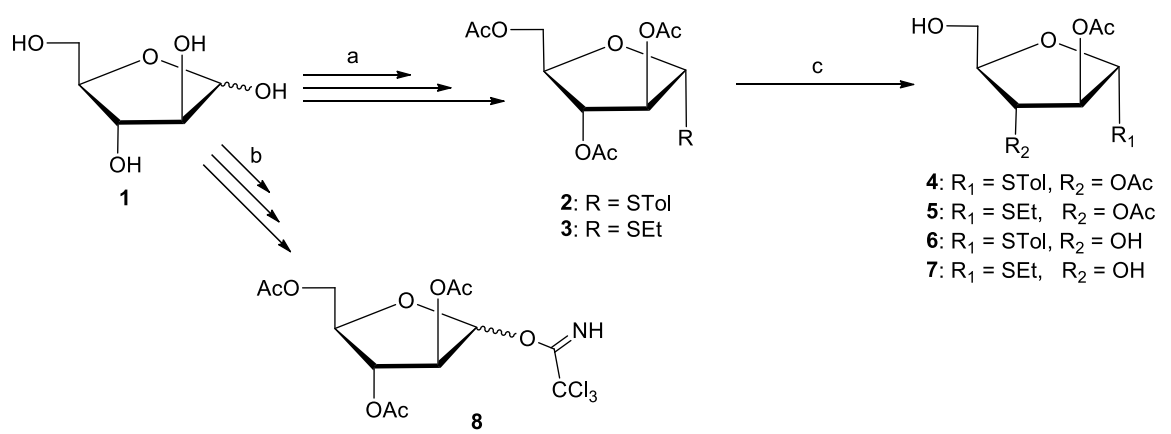

Scheme 1. Reagents and conditions: Transformations (a) and (b) have been conducted using reported protocols[25,27]; (c) CALB (Nvozyme 435), $t$ - BuOH (4\% water) (4 and 5) / $t$ - $\mathrm{BuOH}\left(8 \%\right.$ water) $\left(\mathbf{6}\right.$ and 7 ), $60{ }^{\circ} \mathrm{C}$, 1000 rpm, 15 h (4 and 5) / 80 h (6 and 7), 65\% (4), 43\% (5), 65\% (6), 48\% (7), respectively.

As shown in Scheme 1, the synthesis of monosaccharides $\mathbf{2}$ and $\mathbf{3}$ started with commercially available D-arabinose 1. Since both furanose and pyranose forms can be obtained during the one step acetylation of D-arabinose, hydroxy group at C-1 or C-5 position needs to be protected first. Thus, peracetylated arabinofuranose was synthesized by three steps which are anomeric methoxy introduction, acetylization and anomeric acetylization[25]. Then, Lewis acid was used to activate the anomeric position introducing the sulfur group to afford compounds $\mathbf{2}$ and $\mathbf{3}$ at low temperature. After that, enzymatic reactions catalyzed by immobilized CALB (Nvozyme 435) were performed to selectively remove the acetyl group only in C-5 (products $\mathbf{4}$ and 5) and in both C-3 and C-5 (products 6 and 7). From ${ }^{1} \mathrm{H}$ NMR and ${ }^{1} \mathrm{H}-{ }^{1} \mathrm{H}$ COSY spectra (see supporting information), the acetyl on C-5 position was first deprotected before the removal of C-3 acetyl. And compared to taking monosaccharide $\mathbf{3}$ as raw material, compound $\mathbf{2}$ can remove both acetyls on C-3 and C-5 positions with higher yield implying that building block $\mathbf{2}$ is more suitable as an intermediate for further synthesis. Afterwards, the conditions for the optimization of the selective hydrolysis of substrate $\mathbf{2}$ in C-5 position to obtain products $\mathbf{4}$, and in C-5 and C-3 for synthesis of intermediate 6, were tested and reported in the supporting information (table S1 and S2). From results obtained by adjusting water and enzyme amounts, as well as controlling the reaction time, it was deduced that larger amounts of water and enzyme along with longer reaction time promoted the deprotection of two acetyls.

A flow chemistry approach was also considered for the enzymatic deprotection of thioglycosyl arabinose $\mathbf{2}$ since immobilized CALB was reported to dramatically improve performance in the 
regioselective hydrolysis of peracetylated arabinose[26]. Thus, immobilized CALB was packed into a glass column and a solution of $\mathbf{2}$ in $t$ - $\mathrm{BuOH} /$ water flowed through it. Reaction parameters (i.e., concentration, amount of water, temperature, pressure and residence time) have been optimized for the preparation of intermediates $\mathbf{4}$ and $\mathbf{6}$ according to the experiment reported in the additional information (Table S3 and S4). All the optimization studies were performed with the same bioreactor without observing any relevant loss of activity. Thus the column reactor can be used to perform in continuous flow reaction for at least $100 \mathrm{~h}$ in the condition used (working in $t$ - $\mathrm{BuOH}$ with water between $2 \%$ and $10 \% ; 60^{\circ} \mathrm{C}$ and atmospheric pressure). In the hydrolysis of thiglycosyl arabinose 2, the reaction outcome improved compared with the results obtained by batch (Table 1). Thus, 67\% yield of product 4 was obtained in only one half hour, while substrate 2 was completely converted into product 6 ( $98 \%$ by HPLC analysis of the reaction) after 18 hours of recirculation in flow condition. The system was then tested in the synthesis of intermediate 6 on the preparative gram scale. Recirculating the substrate solution for $48 \mathrm{~h}$ (Table 1), less than 350 $\mathrm{mg}$ of biocatalyst was able to efficiently hydrolyse $880 \mathrm{mg}$ of $\mathbf{2}$ allowing the production of $\mathbf{6}$ in $80 \%$ yield after purification.

Table 1. Performances obtained in the hydrolysis of substrate $\mathbf{2}$ catalyzed by immobilized CALB

\begin{tabular}{|c|c|c|c|c|c|c|}
\hline Entry & Substrate $\mathbf{2}$ & Enzyme & Product & Condition & Time & Yields \\
\hline 1 & $30 \mathrm{mg}$ & $150 \mathrm{mg}$ & 4 & Batch $^{\text {(a) }}$ & $15 \mathrm{~h}$ & $65 \%$ \\
\hline 2 & $90 \mathrm{mg}$ & $345 \mathrm{mg}$ & 4 & Flow (b) & $0.5 \mathrm{~h}$ & $67 \%$ \\
\hline 3 & $36 \mathrm{mg}$ & $150 \mathrm{mg}$ & 6 & Batch $^{(c)}$ & $80 \mathrm{~h}$ & $65 \%$ \\
\hline 4 & $75 \mathrm{mg}$ & $345 \mathrm{mg}$ & 6 & Flow $^{(d)}$ & $18 \mathrm{~h}$ & 98\% (HPLC) \\
\hline 5 & $880 \mathrm{mg}$ & $345 \mathrm{mg}$ & 6 & Flow (e) & $48 \mathrm{~h}$ & $80 \%$ \\
\hline
\end{tabular}

Batch: (a) $t$ - $\mathrm{BuOH}$ (water $8 \%$ ), volume: $1.2 \mathrm{~mL}, 1000 \mathrm{rpm}, 60^{\circ} \mathrm{C}$; (c) $t$-BuOH (water $8 \%$ ), volume: $1.2 \mathrm{~mL}, 1000$ $\mathrm{rpm}, 60^{\circ} \mathrm{C}$; Flow: All the conditions use bioreactor volume: $1.54 \mathrm{~mL} .60^{\circ} \mathrm{C}$; substrate 2 concentration: $25 \mathrm{mg} / \mathrm{mL}$ : (b) $t-\mathrm{BuOH}$ (water $4 \%$ ), flow rate $52 \mu \mathrm{L} / \mathrm{min}$, pressure: Atm. (d) $t$ - $\mathrm{BuOH}$ (water $4 \%$ ); Recirculation: flow rate 52 $\mu \mathrm{L} / \mathrm{min}$, pressure: Atm. Conversion calculated by HPLC analysis. (e) t-BuOH (water $2 \%$ ); Recirculation: flow rate $104 \mu \mathrm{L} / \mathrm{min}$; pressure: 75 psi.

On the other hand, metal catalyst was applied to remove the anomeric acetyl in peracetylated arabinofuranose followed by imidate introduction to prepare monosaccharide $\mathbf{8}$ according to the 
known approaches[27].

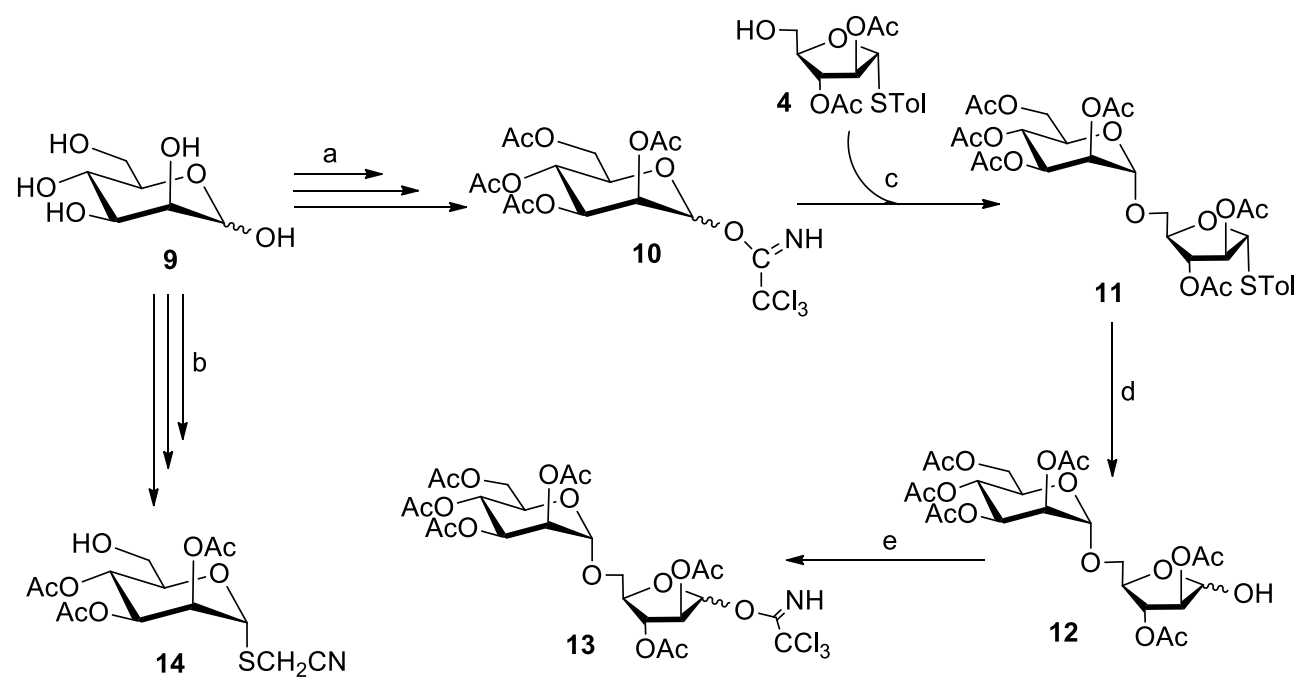

Scheme 2. Reagents and conditions: Transformations (a) and (b) have been conducted using reported protocols[23,28]; (c) $\mathrm{BF}_{3} \cdot \mathrm{Et}_{2} \mathrm{O}, 4 \AA \mathrm{MS}, \mathrm{CH}_{2} \mathrm{Cl}_{2},-60{ }^{\circ} \mathrm{C}, 30 \mathrm{~min}, 55 \%$; (d) NIS, AgOTf, TTBP, wet $\mathrm{CH}_{2} \mathrm{Cl}_{2}, 0{ }^{\circ} \mathrm{C}$ RT, 1 h, $90 \%$; (e) $\mathrm{CCl}_{3} \mathrm{CN}, \mathrm{DBU}, \mathrm{CH}_{2} \mathrm{Cl}_{2}, 0{ }^{\circ} \mathrm{C}, 30 \mathrm{~min}, 90 \%$.

In Scheme 2, D-mannose was used as starting material to synthesize monosaccharide trichloroacetimidate $\mathbf{1 0}$ as intermediate by the reported methods[28]. After that, glycosylation was performed using donor $\mathbf{1 0}$ and acceptor $\mathbf{4}$ catalyzed by $\mathrm{BF}_{3} \cdot \mathrm{Et}_{2} \mathrm{O}$ at low temperature. In this step, we found that reaction temperature has an effect on the preferred reaction pathway, and low temperature can avoid the byproduct to some degree. When reaction was carried out at $0{ }^{\circ} \mathrm{C}$, almost no targeting product was obtained because the Lewis acid activated the STol group in compound 4 , and when the temperature decreased to $-30{ }^{\circ} \mathrm{C}$ and $-60{ }^{\circ} \mathrm{C}$, the yield came to $40 \%$ and $55 \%$, respectively. However, no increase of the output was observed when temperature continued declining implying that $-60{ }^{\circ} \mathrm{C}$ is the proper temperature balancing the yield and economic cost. Afterwards, the sulfur group in compound $\mathbf{1 1}$ was removed by NIS/AgOTf and 2,4,6-Tri-tert-butylpyrimidine (TTBP) in wet $\mathrm{CH}_{2} \mathrm{Cl}_{2}$ obtaining compound $\mathbf{1 2}$ with free hydroxy at the anomeric center, and finally intermediate $\mathbf{1 2}$ was transformed into trichloroacetimidate $\mathbf{1 3}$ at $0{ }^{\circ} \mathrm{C}$ with $\mathrm{CCl}_{3} \mathrm{CN}$ and $\mathrm{DBU}$ for further use. On the other hand, the known compound $\mathbf{1 4}$ was synthesized by several steps, including a final enzymatic hydrolysis catalyzed by Candida rugose lipase for deprotection in C-6, according to the literature[23]. 


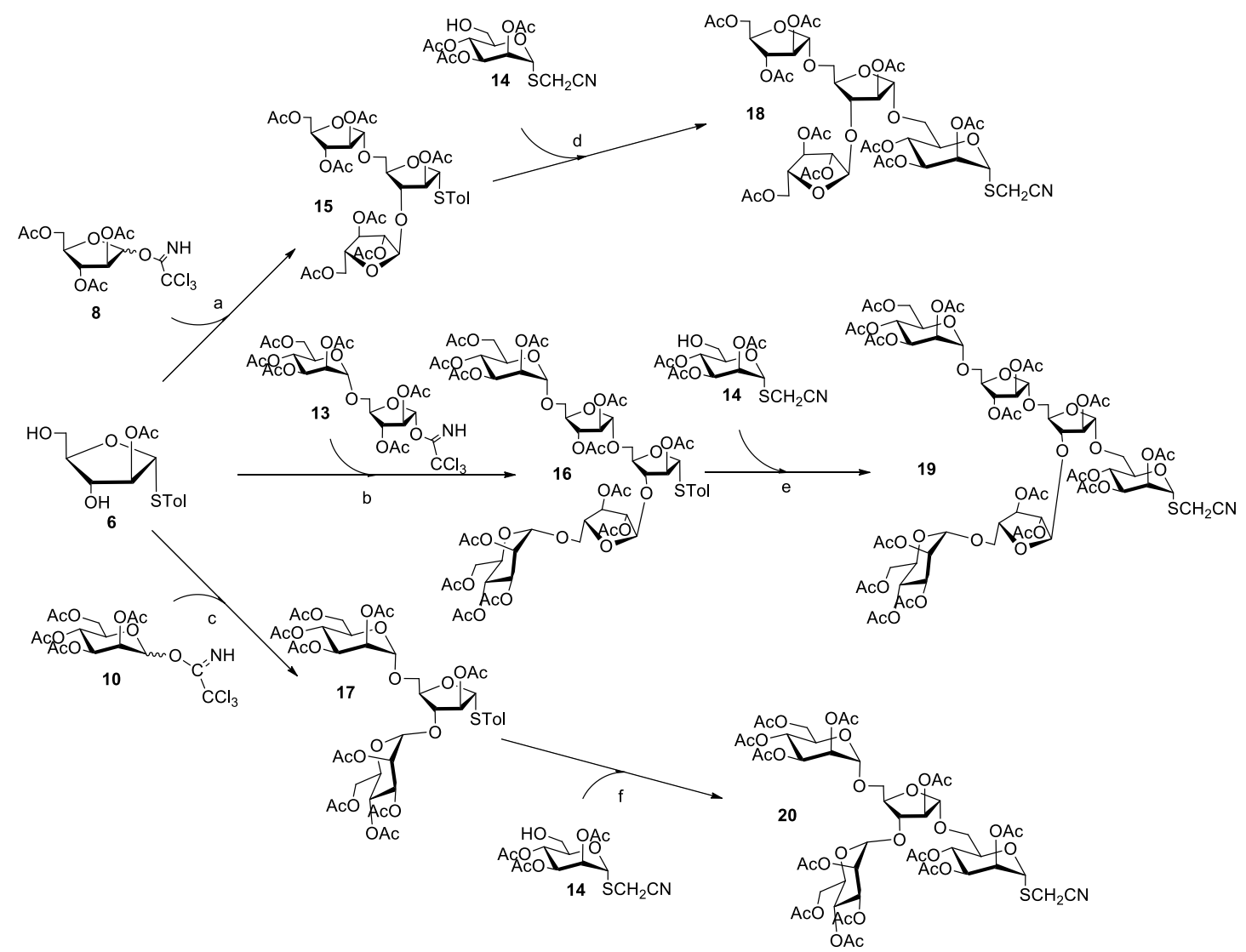

Scheme 3. Reagents and conditions: (a) $\mathrm{BF}_{3} \cdot \mathrm{Et}_{2} \mathrm{O}, 4 \AA \mathrm{MS}, \mathrm{CH}_{2} \mathrm{Cl}_{2}, 0{ }^{\circ} \mathrm{C}, 30 \mathrm{~min}, 40 \%$; (b) $\mathrm{BF}_{3} \cdot \mathrm{Et}_{2} \mathrm{O}, 4 \AA \mathrm{MS}$, $\mathrm{CH}_{2} \mathrm{Cl}_{2}, 0{ }^{\circ} \mathrm{C}, 1 \mathrm{~h}, 32 \%$; (c) $\mathrm{BF}_{3} \cdot \mathrm{Et}_{2} \mathrm{O}, 4 \AA \mathrm{MS}, \mathrm{CH}_{2} \mathrm{Cl}_{2}, 0{ }^{\circ} \mathrm{C}, 1 \mathrm{~h}, 37 \%$; (d) NIS, AgOTf, $4 \AA \mathrm{MS}, \mathrm{CH}_{2} \mathrm{Cl}_{2},-30{ }^{\circ} \mathrm{C}$, $50 \mathrm{~min}, 60 \%$; (e) NIS, AgOTf, $4 \AA \mathrm{MS}, \mathrm{CH}_{2} \mathrm{Cl}_{2},-30{ }^{\circ} \mathrm{C}, 50 \mathrm{~min}, 49 \%$; (f) NIS, AgOTf, $4 \AA \mathrm{MS}, \mathrm{CH}_{2} \mathrm{Cl}_{2},-30{ }^{\circ} \mathrm{C}, 50$ $\min , 55 \%$

With the three donors prepared $(\mathbf{8}, \mathbf{1 0}$ and $\mathbf{1 3})$, glycosylations were carried out with acceptor $\mathbf{6}$, (Scheme 3). Since catalyst and temperature may affect the reaction, different conditions were studied. For the reason that both $\mathrm{BF}_{3} \cdot \mathrm{Et}_{2} \mathrm{O}$ and TMSOTf were taken as promoters for the glycosylation, with $\mathrm{BF}_{3} \cdot \mathrm{Et}_{2} \mathrm{O}$ providing more products than TMSOTf, only the former promoter was studied in Table 2. In Entry 1, since $\mathrm{BF}_{3} \cdot \mathrm{Et}_{2} \mathrm{O}$ activated the STol group in acceptor $\mathbf{6}$ at $-30{ }^{\circ} \mathrm{C}$, hardly any product 15 was obtained. Then with temperature cooled to $-50{ }^{\circ} \mathrm{C}$ and $-60{ }^{\circ} \mathrm{C}$ in Entry 2 and 3, the yield went up to $29 \%$ and $40 \%$, respectively. However, a continued reduction of temperature to $-70{ }^{\circ} \mathrm{C}$ did not increase the yield in Entry 6, indicating that $-60{ }^{\circ} \mathrm{C}$ is proper for producing 15. In addition to this, the quantity of catalyst was also studied in the Table. In Entry 4, less product was obtained by adding more catalyst at $-60{ }^{\circ} \mathrm{C}$. With less $\mathrm{BF}_{3} \cdot \mathrm{Et}_{2} \mathrm{O}$ promoter (Entry 5), the yield also appeared to decrease, because it needs a longer time to finish the reaction which is detrimental for a stable experimental condition. 
Similarly, for constructing compound $\mathbf{1 7}$, low temperature is beneficial to obtain product $\mathbf{1 7}$ in decent yield. Compared to Entry 7-9, Entry10 provided a higher yield (23\%) using the same amount of catalyst. However, deceasing the temperature in Entry 13 did not result in a better output than in Entry 10. In addition, comparison of Entry 10, 11 and 12 demonstrated that reducing the catalyst quantity could enhance the reaction yield, whereas increasing the quantity may decrease the yield and the best result acquired is shown in Entry 12.

Subsequently, different conditions were also studied for synthesizing pentasaccharide 16. From the results, in Entry 14, 15 and 18, $-60{ }^{\circ} \mathrm{C}$ is the optimal temperature to construct 16 with yield reaching 37\%. In Entry 17, doubling the amount of promoter cut down the yield from 37\% to $25 \%$ at the same temperature, while decreasing it to 0.2 equiv. did not affect the yield in Entry 16.

Table 2. Conditions studied to furnish compounds 15-17

\begin{tabular}{ccccccc}
\hline Entry & Donor & Acceptor & Temperature & $\begin{array}{c}\text { Catalyst } \\
\text { (equiv.) }\end{array}$ & Product & Yield \\
\hline $\mathbf{1}$ & $\mathbf{8}$ & $\mathbf{6}$ & $-30{ }^{\circ} \mathrm{C}$ & 0.5 & $\mathbf{1 5}$ & $<10 \%$ \\
$\mathbf{2}$ & $\mathbf{8}$ & $\mathbf{6}$ & $-50{ }^{\circ} \mathrm{C}$ & 0.5 & $\mathbf{1 5}$ & $29 \%$ \\
$\mathbf{3}$ & $\mathbf{8}$ & $\mathbf{6}$ & $-60{ }^{\circ} \mathrm{C}$ & 0.5 & $\mathbf{1 5}$ & $40 \%$ \\
$\mathbf{4}$ & $\mathbf{8}$ & $\mathbf{6}$ & $-60{ }^{\circ} \mathrm{C}$ & 1 & $\mathbf{1 5}$ & $33 \%$ \\
$\mathbf{5}$ & $\mathbf{8}$ & $\mathbf{6}$ & $-60{ }^{\circ} \mathrm{C}$ & 0.2 & $\mathbf{1 5}$ & $37 \%$ \\
$\mathbf{6}$ & $\mathbf{8}$ & $\mathbf{6}$ & $-70{ }^{\circ} \mathrm{C}$ & 0.5 & $\mathbf{1 5}$ & $35 \%$ \\
$\mathbf{7}$ & $\mathbf{1 0}$ & $\mathbf{6}$ & $-30{ }^{\circ} \mathrm{C}$ & 0.5 & $\mathbf{1 7}$ & $<10 \%$ \\
$\mathbf{8}$ & $\mathbf{1 0}$ & $\mathbf{6}$ & $-50{ }^{\circ} \mathrm{C}$ & 0.5 & $\mathbf{1 7}$ & $<10 \%$ \\
$\mathbf{9}$ & $\mathbf{1 0}$ & $\mathbf{6}$ & $-60{ }^{\circ} \mathrm{C}$ & 0.5 & $\mathbf{1 7}$ & $18 \%$ \\
$\mathbf{1 0}$ & $\mathbf{1 0}$ & $\mathbf{6}$ & $-70{ }^{\circ} \mathrm{C}$ & 0.5 & $\mathbf{1 7}$ & $23 \%$ \\
$\mathbf{1 1}$ & $\mathbf{1 0}$ & $\mathbf{6}$ & $-70{ }^{\circ} \mathrm{C}$ & 1 & $\mathbf{1 7}$ & $11 \%$ \\
$\mathbf{1 2}$ & $\mathbf{1 0}$ & $\mathbf{6}$ & $-70{ }^{\circ} \mathrm{C}$ & 0.2 & $\mathbf{1 7}$ & $32 \%$ \\
$\mathbf{1 3}$ & $\mathbf{1 0}$ & $\mathbf{6}$ & $-90{ }^{\circ} \mathrm{C}$ & 0.5 & $\mathbf{1 7}$ & $17 \%$ \\
$\mathbf{1 4}$ & $\mathbf{1 3}$ & $\mathbf{6}$ & $-50{ }^{\circ} \mathrm{C}$ & 0.5 & $\mathbf{1 6}$ & $35 \%$ \\
$\mathbf{1 5}$ & $\mathbf{1 3}$ & $\mathbf{6}$ & $-60{ }^{\circ} \mathrm{C}$ & 0.5 & $\mathbf{1 6}$ & $37 \%$ \\
$\mathbf{1 6}$ & $\mathbf{1 3}$ & $\mathbf{6}$ & $-60{ }^{\circ} \mathrm{C}$ & 0.2 & $\mathbf{1 6}$ & $37 \%$ \\
$\mathbf{1 7}$ & $\mathbf{1 3}$ & $\mathbf{6}$ & $-60{ }^{\circ} \mathrm{C}$ & 1 & $\mathbf{1 6}$ & $25 \%$ \\
$\mathbf{1 8}$ & $\mathbf{1 3}$ & $\mathbf{6}$ & $-70{ }^{\circ} \mathrm{C}$ & 0.5 & $\mathbf{1 6}$ & $34 \%$ \\
\hline
\end{tabular}

*In the table, all the conditions are donor being 3 equiv. and acceptor being 1 equiv.

Finally, promoted by NIS/AgOTf, glycoylations were performed between the three synthesized donors $(15,16$ and 17) and acceptor 14, respectively. In Scheme 3, monosaccharide 14 is a known 
compound synthesized by enzymatic hydrolysis[23], where there is a $\mathrm{SCH}_{2} \mathrm{CN}$ group at the anomeric centre in $\mathbf{1 4}$ that may be damaged by using the same reagent. Since in $\mathrm{SCH}_{2} \mathrm{CN}$ the cyano group is an electron withdrawing group, it can reduce the electronic cloud density around sulfur. Besides, furanose (donors 15, 16 and 17) is general more activated than pyranose (acceptor 14) in glycosylation. We propose the catalyst would activate the STol groups in the donor first. In this step, the reactions were carried out at $-10{ }^{\circ} \mathrm{C},-30{ }^{\circ} \mathrm{C}$ and $-50{ }^{\circ} \mathrm{C}$, respectively, and $-30{ }^{\circ} \mathrm{C}$ provided the best yield. Finally, two tetrasaccharides (18 and 20) and one hexasaccharide (19) were obtained for further protein conjugation via thiocyanomethyl group.

\subsection{Preparation of the glycoconjugates}

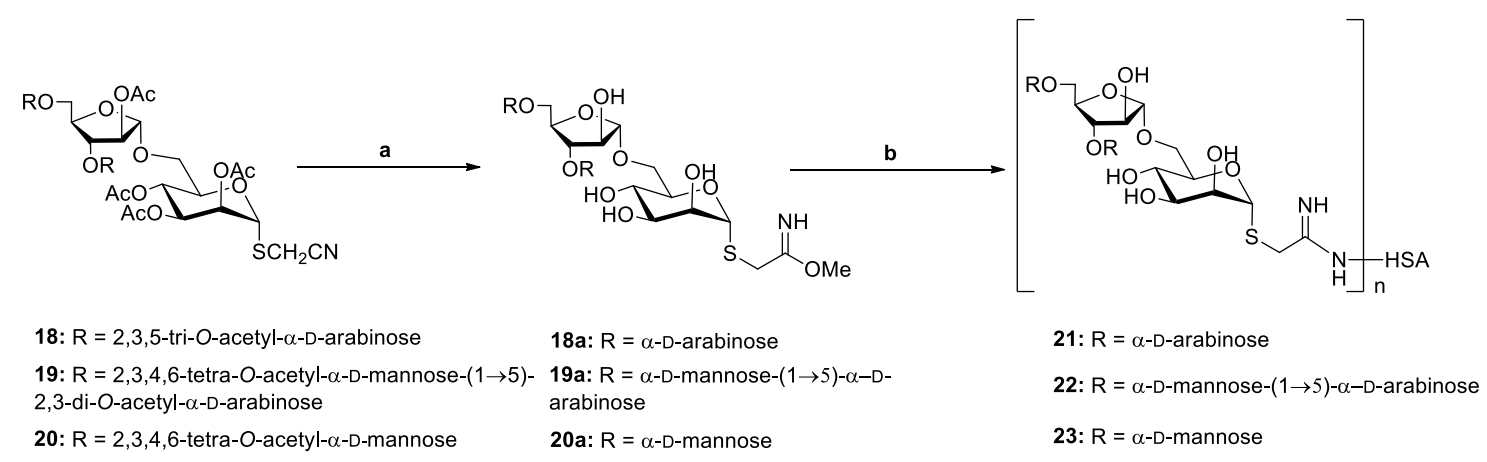

Scheme 4. Reagents and conditions: (a) 21-23, $\mathrm{MeONa} / \mathrm{MeOH}, 35^{\circ} \mathrm{C}, 48 \mathrm{~h}$; (b) rHSA, sodium tetraborate buffer,

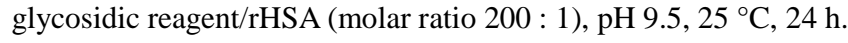

As shown in Scheme 4, compounds 18-20 were submitted to one pot deacetylation and activation to obtain the corresponding 2-deprotected iminomethoxyethyl (IME) thioglycosides 18a-20a. The reactions were performed according to a previously reported procedure[17,23], working at $35^{\circ} \mathrm{C}$ in order to achieve a conversion around $50 \%$ of each intermediate into the corresponding IME derivative (Table 3), as resulting from ESI-MS analysis (see Figure S1-S3 in supplementary information).

The coupling reactions between activated glycans 18a-20a and the carrier protein, namely rHSA, were carried out according to a previously reported protocol for IME-activated saccharides that is specific for lysine residues[17]. Starting from literature conditions, different reaction parameters (temperature, saccharide/protein ratio, reaction temperature and time, presence of 
organic solvent) were tested in order to reach satisfactory conjugation yields. For this purpose, reaction mixtures were analysed by direct injection in Hydrophilic Interaction Liquid Chromatography (HILIC-UV). In HILIC chromatography, the stationary phase (for our column composed of amide-derivatized silica) interacts with the sugar moieties of glycoproteins or glycoconjugates thanks to its high hydrophilicity, and the resulting elution order reflects the degree of glycosylation. Nowadays, HILIC analysis at intact protein level is considered a consolidated approach in glycoprofiling studies[29].

Collecting all the different observations, the final glycosylation protocol was developed. The HILIC-UV trace of neo-glycoprotein $\mathbf{2 1 - 2 3}$ obtained in the optimized conditions were reported in Figure S4 supplementary data, where the absence of chromatographic peaks at the retention time of rHSA indicated that all three glycosylations were completed after 24 h (Table 3). Finally, MALDI-ToF analysis was performed for the characterization of the different neoglycoproteins. Based upon the mass difference between un-conjugated HSA and each of the 3 conjugated compounds, it was possible to estimate the average level of conjugation (average number of oligosaccharides attached) for each sample (Table 3).

Table 3. Results of the coupling reaction by $\mathbf{1 8 - 2 0}$

\begin{tabular}{cccc}
\hline Compound & IME-derivative (\%) ${ }^{(\mathbf{a})}$ & Product (\%) $^{(\mathbf{b})}$ & $\mathbf{n}^{\circ}$ sugar \\
\hline $\mathbf{1 8}$ & $\mathbf{1 8 a}(49 \%)$ & $\mathbf{2 1}(>98 \%)$ & 14.5 \\
$\mathbf{1 9}$ & $\mathbf{1 9 a}(53 \%)$ & $\mathbf{2 2}(>98 \%)$ & 12.4 \\
$\mathbf{2 0}$ & $\mathbf{2 0 a}(54 \%)$ & $\mathbf{2 3}(>98 \%)$ & 14.3 \\
\hline
\end{tabular}

\subsection{Biological ex-vivo evaluation of the glycoconjugates}

Ex-vivo antigenic evaluation has been performed with neo-glycoproteins $\mathbf{2 1 - 2 3}$, in order to evaluate the affinity of putative epitopes for human antibodies. This approach is an elective method for the screening of new antigens because it is directly related to the recognition of human epitopes and allows an appropriate selection of candidates for successive in vivo testing. Thus, indirect ELISA (Figure 4) was applied using serum obtained from infected patient (30 individuals) to detect the potential of 21 (ManAra3-rHSA), 22 (Man3Ara3-rHSA) and 23 (Man3Ara-rHSA) as 
antigens and 16 healthy members' serum as controls (details such as age and nationality are shown in Table S5). The results from this analysis demonstrated a statistically significant increase of the antibody reactivity in TB subjects compared with healthy control ones for neoglycoproteins 21 and $22(\mathrm{p} \leq 0.0004$ and $\mathrm{p} \leq 0.01$ respectively).

In the test, the obtained cut-off value of the rHSA-based ELISA was 0.380 (mean $=0.128, \mathrm{SD}=$ 0.084), while the cut-off value of the 21, 22 and 23-based ELISA was 0.482 (mean $=0.168, \mathrm{SD}=$ $0.105), 0.298($ mean $=0.106, \mathrm{SD}=0.064)$, and 0.307 (mean $=0.121, \mathrm{SD}=0.062)$, respectively. In these conditions on a total of $30 \mathrm{~TB}$ serum samples, 17 were determined as positive for product 21 $($ mean $=0.767, \mathrm{SD}=0.619), 13$ for neoglycoprotein $22($ mean $=0.471, \mathrm{SD}=0.539)$ and only 2 for $23($ mean $=0.175, \mathrm{SD}=0.125)$.
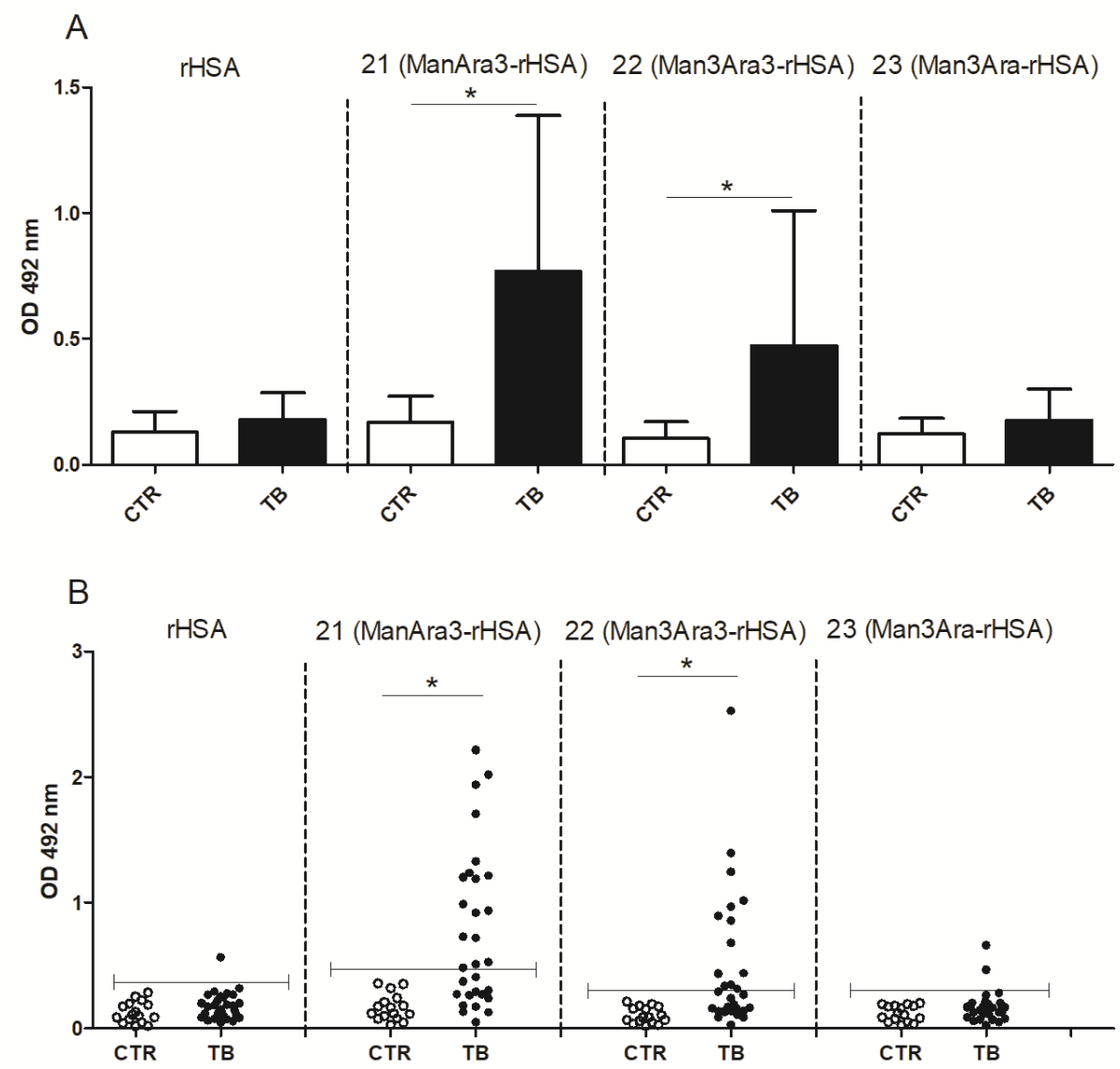

Figure 4. Antibodies ( $\operatorname{IgG}$ ) levels reactive against neoglycoproteins 21, 22 and 23 in $30 \mathrm{~TB}$ patients and 16 healthy subjects (CTR).

In the figure, rHSA was used as protein control. Panel A: Histograms report OD mean values and standard deviation of TB and control samples. Panel B: Distribution of IgG level of samples. Horizontal lines represents the cut off values calculated for each antigens used in the study as the average of negative controls $+(3 \times \mathrm{SD}$ of negative controls). The sera above horizontal line were considered positive and sera below the line were negative 
according to the cut off value. $\mathrm{OD}=$ Optical Density; CTR: Controls; $\mathrm{TB}=$ Tuberculosis. $P \leq 0.05=*$.

The analysis of antibody specificity to different neoglycoproteins of sera from M.TB patients demonstrated that the D-Ara motif branched with D-Ara $\alpha(1 \rightarrow 5)$ and $\alpha(1 \rightarrow 3)$, contained in compound 21, is well recognized by antibodies from 17 out of 30 patients. The replacement of the two D-Ara residues with two D-Man $\alpha(1 \rightarrow 5)$ units (compound 23), completely abrogated the reactivity of antibodies. The activity is partially maintained when two additional units of D-Man- $\alpha(1 \rightarrow 5)$ are introduced on the branched D-Ara motif to obtain compound 22.

Interestingly, the analysis of the 13 patients positively responding to the neoglycoprotein $\mathbf{2 2}$ are almost all revealing positive for glycoconjugate 21 (in Figure 5) (except for one patient that is purely responding towards both sugars), while only about $70 \%$ of the 17 patients responding for antigen $\mathbf{2 1}$ are positive for $\mathbf{2 2}$. These results may indicate that the epitope of $\mathbf{2 2}$ is correlated with the branched D-Ara motif contained in $\mathbf{2 1}$ and the introduction of two additional mannose molecules at the end of the chain reduces the recognition of this epitope.

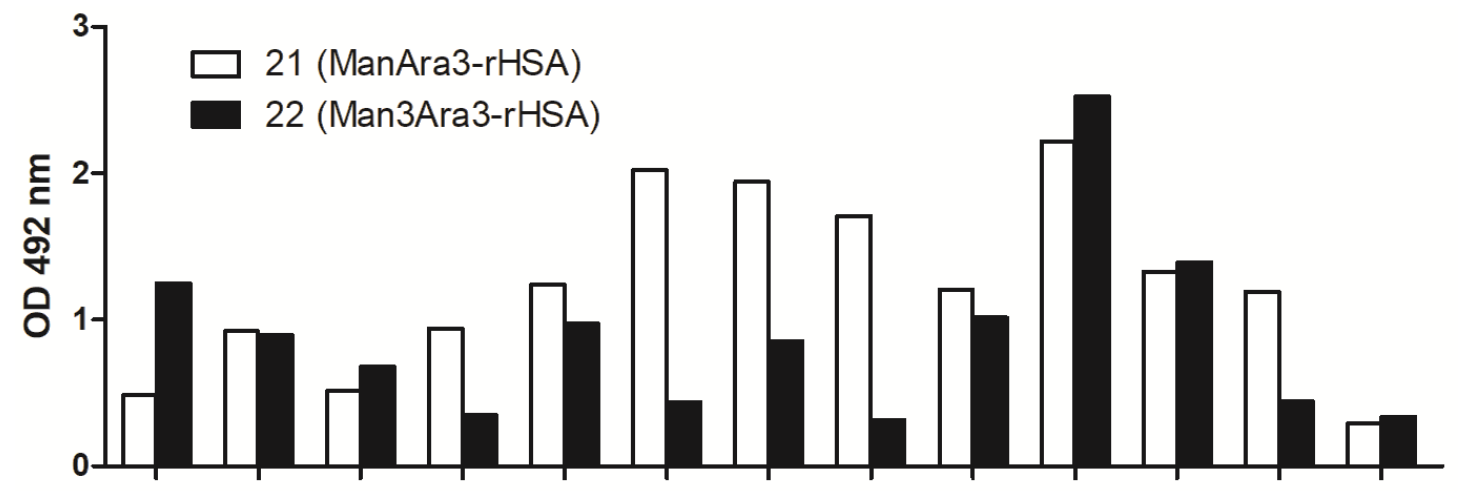

Figure 5. OD values obtained with the M.TB patients that respond positively against compound 22

As one of the most convenient and rapid technologies in immunoassay, ELISA plays an essential role in TB ex-vivo biological evaluation because of its sensitivity and specificity for human antibodies. However, most of the research used mice as the experimental model[16, 30, 31], which may lead to different results than humans epitopes. In this work, we use the serum obtained from different infected patients to evaluate the prepared compounds and our study demonstrates 
that the branched D-Ara motif included in different parts of the AM structure can have significance as a human epitope and thus relevant in developing novel TB vaccine candidates.

\section{Conclusion}

A novel enzymatic approach was developed to selectively remove acetyls from a peracetylated arabinose thioglycoside furnishing a key building block for synthesizing three branched AM analogues. The flow chemistry application through immobilized CALB (Nvozyme 435) in the column bioreactor not only shortened the reaction time, but also enhanced the output significantly on the gram scale. After required steps of glycosylations, three oligosaccharides derived from AM were furnished and conjugated with rHSA. In the ELISA test, the three glycoconjugates showed different affinities to human antibodies present in the serum of M.TB infected patients, with compound 21 obtaining the best results. The fact that the number of patients responding to 21 and the mean response observed by ex-vivo assay to $\mathbf{2 1}$ were much greater than the responses obtained by the two other analogues prepared with the same synthetic approach, demonstrates that the branched arabinose motif contained in neo-glycoprotein $\mathbf{2 1}$ is a putative human epitope of LAM. Thus, neo-glycoprotein based on branched D-Ara motif are prone to induce production of specific human antibodies against LAM and are worthy of further investigation.

In order to find out the best epitopes of AM and design more effective antituberculosis vaccine candidates, $\mathbf{2 1}$ can be regarded as the lead compound to prepare more related compounds including the use of suitable carrier proteins for in-vivo evaluation. It is noteworthy that this is the first work using the chemo-enzymatic approach and it represents a method to rapidly synthesize new branched analogues in order to better elucidate the antigenic structures of AM. In this context, the use of biological evaluation by ex-vivo tests is also helpful to identify the optimal human epitope(s) and design novel efficient AM-based TB glycovaccine candidates for further evaluation. Furthermore, studies such as in vivo evaluations on suitable animal models will also be considered in the future for selected compounds.

\section{Experimental Section}

\subsection{General method}


All chemicals were purchased as reagent grade and used without further purification. All reactions were carried out under $\mathrm{Ar}$ atmosphere and anhydrous conditions with freshly distilled solvents, unless otherwise noted. Reactions were monitored by thin layer chromatography (TLC) on a pre-coated plate of silica gel 60 F254 (Merck) and detection by charring with sulfuric acid. Solvents were evaporated under reduced pressure and below $40{ }^{\circ} \mathrm{C}$ (water bath). Column chromatography was performed on silica gel 60 (230-400 mesh, Merck). All the new compounds were fully characterized by ${ }^{1} \mathrm{H}$ and ${ }^{13} \mathrm{C}$ NMR, as well as HRMS. ${ }^{1} \mathrm{H}$ NMR and ${ }^{13} \mathrm{C}$ NMR spectra were recorded at $400 \mathrm{MHz}$ and $100 \mathrm{MHz}$ with Bruker AVANCE DRX 400 spectrometer, respectively. The chemical shifts were referenced to the solvent peak, $7.26 \mathrm{ppm}\left({ }^{1} \mathrm{H}\right)$ and 77.16 ppm $\left({ }^{13} \mathrm{C}\right)$ for $\mathrm{CDCl}_{3}$ at $25{ }^{\circ} \mathrm{C}$, and coupling constants were given in $\mathrm{Hz}$. Complete assignment of all NMR signals was performed using a combination of ${ }^{1} \mathrm{H},{ }^{1} \mathrm{H}-\mathrm{COSY}$ and ${ }^{1} \mathrm{H},{ }^{13} \mathrm{C}-\mathrm{HSQC}$ experiments. For characterization of the synthetic intermediates and oligosaccharides high-resolution mass spectra (HRMS) were recorded with a Bruker Micro-TOF spectrometer in electrospray ionization (ESI) mode, using Tuning-Mix as reference. The continuous flow reactions were performed using a R2+/R4 series flow reactor, commercially available from Vapourtec equipped with Omnifit glass columns. For the preparation of the different neo-glycoprotein, rHSA (recombinant human serum albumin) is derived from rice grains (gene-modified rice endosperm) and obtained by chromatographic purification (>99\% by SDS-PAGE) was provided by Healtgen biotechnology Corp (Wuhan, China).

\subsection{Synthesis of the AM analogues}

4.2.1 4-Methylphenyl 2,3-di- $O$-acetyl-1-thio- $\alpha$-D-arabinofuranoside (4)

4.2.1.1 Batch method: To a solution of $t$-BuOH $(12 \mathrm{~mL})$ with $4 \%$ water $(0.84 \mathrm{~mL})$ added, compound $2(600 \mathrm{mg}, 1.6 \mathrm{mmol})$ and CALB enzyme $(1.5 \mathrm{~g})$ were added. Then the reaction was stirred vigorously at $1000 \mathrm{rpm}$ at $60{ }^{\circ} \mathrm{C}$ for $15 \mathrm{~h}$. After filtrating the enzyme, the solution was concentrated under vacuum before purification by column chromatography (cyclohexane: ethyl acetate $=2: 1)$, with white foam 4 obtained $(360 \mathrm{mg}, 65 \%)$.

4.2.1.2 Flow method: A solution $(25 \mathrm{mg} / \mathrm{mL})$ of substrate 2 was prepared in a mixture water/tert-butanol (96:4). The bioreactor (prepared packing $345 \mathrm{mg}$ CALB into a glass column; volume: $1.54 \mathrm{~mL}$ ) was washed with the flow stream (water/tert-butanol 96:4) at $0.5 \mathrm{~mL} / \mathrm{min}$ for 5 $\min$ at $\mathrm{RT}$ and $5 \mathrm{~min}$ at $60{ }^{\circ} \mathrm{C}$. The substrate solution $(3.6 \mathrm{~mL})$ was then recirculated at $60{ }^{\circ} \mathrm{C}$ through the bioreactor (flow $52 \mu \mathrm{L} / \mathrm{min}$ ). The reaction was monitored by HPLC and after for $18 \mathrm{~h}$ the bioreactor was washed with water/tert-butanol (96:4) at $0.5 \mathrm{~mL} / \mathrm{min}$ for $10 \mathrm{~min}$ at $60{ }^{\circ} \mathrm{C}$. The solvent was evaporated under reduced pressure and the crude was purified by flash chromatography (cyclohexane: ethyl acetate $=1: 1)$ to give pure $4(53 \mathrm{mg}, 67 \%) . \mathrm{R}_{\mathrm{f}}=0.6$ (cyclohexane: ethyl acetate $=1: 1) .[\alpha]_{\mathrm{D}}{ }^{25}+174.1\left(\mathrm{c} 1, \mathrm{CHCl}_{3}\right) .{ }^{1} \mathrm{H} \mathrm{NMR}\left(400 \mathrm{MHz}, \mathrm{CDCl}_{3}\right) \delta 5.47$ (d, $J=2.5 \mathrm{~Hz}, 1 \mathrm{H}, \mathrm{H}-1), 5.30$ (t, $J=2.5 \mathrm{~Hz}, 1 \mathrm{H}, \mathrm{H}-2), 5.12$ (m, 1H, H-3), 4.35 (m, 1H, H-4), 3.93-3.79 (m, 2H, H-5, H-5'), 2.34 (s, 3H, Tol), 2.14 (s, 3H, Ac), 2.09 (s, 3H, Ac), 2.02-1.99 (m, $1 \mathrm{H}, \mathrm{OH}) .{ }^{13} \mathrm{C}$ NMR $\left(100 \mathrm{MHz}, \mathrm{CDCl}_{3}\right) \delta 170.46,169.67,138.16,132.83,129.85,129.58,91.10$ (C-1), 82.59, 81.71, 77.08, 61.57, 21.14, 20.81, 20.76. HR ESI-TOF MS $(\mathrm{m} / \mathrm{z})$ : calcd for 
$\mathrm{C}_{16} \mathrm{H}_{20} \mathrm{O}_{6} \mathrm{SNa}[\mathrm{M}+\mathrm{Na}]^{+}, 363.0873$; found, 363.0880 .

\subsubsection{Ethyl 2,3-O-acetyl-1-thio- $\alpha$-D-arabinofuranoside (5)}

To a solution of $t$ - $\mathrm{BuOH}(12 \mathrm{~mL})$ with $4 \%$ water $(0.84 \mathrm{~mL})$ added, compound $2(510 \mathrm{mg}, 1.6$ $\mathrm{mmol})$ and CALB enzyme (1.5 g) were added. Then the reaction was stirred vigorously at 1000 $\mathrm{rpm}$ at $60{ }^{\circ} \mathrm{C}$ for $15 \mathrm{~h}$. After filtrating the enzyme, the solution was concentrated under vacuum before purification by column chromatography (cyclohexane: ethyl acetate $=3: 2$ ), with white foam 5 obtained (191 mg, 43\%). $R_{\mathrm{f}}=0.5$ (cyclohexane: ethyl acetate $\left.=1: 1\right) .[\alpha]_{\mathrm{D}}{ }^{25}+162.5(\mathrm{c} 1$, $\left.\mathrm{CHCl}_{3}\right) .{ }^{1} \mathrm{H} \mathrm{NMR}\left(400 \mathrm{MHz}, \mathrm{CDCl}_{3}\right) \delta 5.33(\mathrm{~m}, 1 \mathrm{H}, \mathrm{H}-1), 5.14(\mathrm{t}, J=2.0 \mathrm{~Hz}, 1 \mathrm{H}, \mathrm{H}-2), 5.08(\mathrm{~m}$, $1 \mathrm{H}, \mathrm{H}-3), 4.25$ (m, 1H, H-4), 3.92-3.79 (m, 2H, H-5, H-5'), 2.74-2.61 (m, 2H, $\left.\mathrm{SCH}_{2}\right), 2.11(\mathrm{~s}, 3 \mathrm{H}$, Ac), 2.09 (s, 3H, Ac), $2.10(\mathrm{~m}, 1 \mathrm{H}, \mathrm{OH}), 1.3\left(\mathrm{t}, J=7.4 \mathrm{~Hz}, 1 \mathrm{H}, \mathrm{CH}_{3}\right) \cdot{ }^{13} \mathrm{C} \mathrm{NMR}\left(100 \mathrm{MHz}, \mathrm{CDCl}_{3}\right)$ $\delta 170.51,169.76,87.57$ (C-1), 82.28, 82.17, 77.29, 61.66, 25.17, 20.81, 20.79, 14.72. calcd for $\mathrm{C}_{11} \mathrm{H}_{18} \mathrm{O}_{6} \mathrm{SNa}[\mathrm{M}+\mathrm{Na}]^{+}, 301.0716$; found, 301.0724 .

\subsubsection{4-Methylphenyl 2-O-acetyl-1-thio- $\alpha$-D-arabinofuranoside (6)}

4.2.3.1 Batch method: To a solution of $t$-BuOH $(12 \mathrm{~mL})$ with $8 \%$ water $(0.84 \mathrm{~mL})$ added, compound $2(600 \mathrm{mg}, 1.6 \mathrm{mmol})$ and CALB enzyme $(1.5 \mathrm{~g})$ were added. Then the reaction was stirred vigorously at $1000 \mathrm{rpm}$ at $60{ }^{\circ} \mathrm{C}$ for $80 \mathrm{~h}$. After filtrating the enzyme, the solution was concentrated under vacuum before purification by column chromatography (cyclohexane: ethyl acetate $=1: 1)$, with white foam 6 obtained $(304 \mathrm{mg}, 65 \%)$.

4.2.3.2 Flow method: A solution of $\mathbf{2}(25 \mathrm{mg} / \mathrm{mL})$ was prepared in a mixture water/tert-butanol (98:2). The bioreactor (prepared as above described) was washed with the flow stream (water/tert-butanol 98:2) at $0.5 \mathrm{~mL} / \mathrm{min}$ for $5 \mathrm{~min}$ at $\mathrm{RT}$ and $5 \mathrm{~min}$ at $60{ }^{\circ} \mathrm{C}(\mathrm{P}=75 \mathrm{psi}$ ). The substrate solution $(36 \mathrm{~mL})$ was then recirculated through the bioreactor at $104 \mu \mathrm{L} / \mathrm{min}\left(60{ }^{\circ} \mathrm{C}, \mathrm{P}\right.$ $=75 \mathrm{psi}$ ). The reaction was monitored by HPLC and after $48 \mathrm{~h}$ the bioreactor was washed with water/tert-butanol $(98: 2)$ at $0.5 \mathrm{~mL} / \mathrm{min}$ for $10 \mathrm{~min}\left(60^{\circ} \mathrm{C}\right)$. The solvent was evaporated under reduced pressure and the crude was purified by flash chromatography (cyclohexane: ethyl acetate $=1: 1)$ to yield $550 \mathrm{mg}$ of pure $4\left(80 \%\right.$ yield). $R_{\mathrm{f}}=0.28$ (cyclohexane: ethyl acetate $\left.=1: 1\right)$. $[\alpha]_{\mathrm{D}}{ }^{25}$ $+184.9\left(\mathrm{c} 0.5, \mathrm{CHCl}_{3}\right) .{ }^{1} \mathrm{H}$ NMR $\left(400 \mathrm{MHz}, \mathrm{CDCl}_{3}\right) \delta 5.51(\mathrm{~d}, J=3.2 \mathrm{~Hz}, 1 \mathrm{H}, \mathrm{H}-1), 4.93(\mathrm{t}, J=$ $3.3 \mathrm{~Hz}, 1 \mathrm{H}, \mathrm{H}-2), 4.30$ (m, 1H, H-4), 4.15 (m, 1H, H-3), 3.91 (m, 1H, H-5), 3.80 (m, 1H, H-5'), 3.49 (s, 1H, OH), 2.33 (s, 3H, Tol), 2.12 (s, 3H, OAc). ${ }^{13} \mathrm{C} \mathrm{NMR}\left(100 \mathrm{MHz}, \mathrm{CDCl}_{3}\right) \delta 172.00$, 138.32, 132.93, 129.96, 129.67, 89.66 (C-1), 86.84, 82.74, 77.48, 77.16, 76.84, 76.25, 61.29, 21.26, 20.95. HR ESI-TOF MS $(\mathrm{m} / \mathrm{z})$ : calcd for $\mathrm{C}_{14} \mathrm{H}_{18} \mathrm{O}_{5} \mathrm{SNH}_{4}\left[\mathrm{M}+\mathrm{NH}_{4}\right]^{+}, 316.1213$; found, 316.1214 .

\subsubsection{Ethyl 2- $O$-acetyl-1-thio- $\alpha$-D-arabinofuranoside (7)}

To a solution of $t$ - $\mathrm{BuOH}(12 \mathrm{~mL})$ with $8 \%$ water $(0.84 \mathrm{~mL})$ added, compound $2(600 \mathrm{mg}, 1.6$ 
mmol) and CALB enzyme (1.5 g) were added. Then the reaction was stirred vigorously at 1000 $\mathrm{rpm}$ at $60{ }^{\circ} \mathrm{C}$ for $80 \mathrm{~h}$. After filtrating the enzyme, the solution was concentrated under vacuum before purification by column chromatography (cyclohexane: ethyl acetate $=1: 1$ ), with white foam 7 obtained $(212 \mathrm{mg}, 48 \%) . \mathrm{R}_{\mathrm{f}}=0.28$ (cyclohexane: ethyl acetate $\left.=1: 1\right) . \quad[\alpha]_{\mathrm{D}}{ }^{25}+164.8(\mathrm{c} 1$, $\left.\mathrm{CHCl}_{3}\right) .{ }^{1} \mathrm{H}$ NMR $\left(400 \mathrm{MHz}, \mathrm{CDCl}_{3}\right) \delta 5.31(\mathrm{~d}, J=2.8 \mathrm{~Hz}, 1 \mathrm{H}, \mathrm{H}-1), 4.73$ (t, $\left.J=3.0 \mathrm{~Hz}, 1 \mathrm{H}, \mathrm{H}-2\right)$, 4.13 (m, 1H, H-4), 4.03 (m, 1H, H-3), 3.85 (m, 1H, H-5), 3.72 (m, 1H, H-5'), 3.29 (d, J = 3.9 Hz, $1 \mathrm{H}, \mathrm{OH}), 2.70-2.54\left(\mathrm{~m}, 2 \mathrm{H}, \mathrm{SCH}_{2}\right), 2.06(\mathrm{~s}, 3 \mathrm{H}, \mathrm{Ac}), 1.25$ (t, $\left.J=7.4 \mathrm{~Hz}, 3 \mathrm{H}, \mathrm{CH}_{3}\right) .{ }^{13} \mathrm{C}$ NMR $(100$ $\left.\mathrm{MHz}, \mathrm{CDCl}_{3}\right) \delta 171.80,87.18(\mathrm{C}-1), 86.06,82.59,76.52,61.37,25.13,20.84,14.68$. $\mathrm{C}_{11} \mathrm{H}_{18} \mathrm{O}_{6} \mathrm{SNa}[\mathrm{M}+\mathrm{Na}]^{+}, 259.0611$; found, 259.0621 .

\subsubsection{4-Methylphenyl}

$(2,3,4,6$-tetra- $O$-acetyl- $\alpha$-D-mannopyranosyl)-( $(1 \rightarrow 5)$-2,3-di- $O$-acetyl-1-thio- $\alpha$-D-arabinofuranoside (11)

The dried compound 4 (300 mg, $0.88 \mathrm{mmol}), 10(650 \mathrm{mg}, 1.32 \mathrm{mmol})$ and activated $4 \AA \mathrm{MS}(1 \mathrm{~g})$ were mixed together in anhydrous $\mathrm{CH}_{2} \mathrm{Cl}_{2}(10 \mathrm{~mL})$ stirred for $1 \mathrm{~h}$ at $\mathrm{RT}$ under argon. Then $\mathrm{BF}_{3} \cdot \mathrm{Et}_{2} \mathrm{O}(63 \mu \mathrm{L}, 0.44 \mathrm{mmol})$ was added and the reaction was left for $30 \mathrm{~min}$ at $-60{ }^{\circ} \mathrm{C}$ before quenching by triethylamine. After filtering by Celite and concentration, the resulting crude product was purified by column chromatography (cyclohexane : ethyl acetate $=3: 2)$ getting $11(325 \mathrm{mg}$, $55 \%)$ as colorless syrup. $\mathrm{R}_{\mathrm{f}}=0.25$ (cyclohexane: ethyl acetate $\left.=3: 2\right) .[\alpha]_{\mathrm{D}}{ }^{25}+133.8\left(\mathrm{c} 1, \mathrm{CHCl}_{3}\right)$. ${ }^{1} \mathrm{H}$ NMR (400 MHz, $\left.\mathrm{CDCl}_{3}\right) \delta 7.40(\mathrm{~d}, J=8.1 \mathrm{~Hz}, 2 \mathrm{H}, \mathrm{Ph}), 7.13(\mathrm{~d}, J=8.1 \mathrm{~Hz}, 2 \mathrm{H}, \mathrm{Ph}), 5.47(\mathrm{~s}$, $\left.1 \mathrm{H}, \mathrm{H}-1^{\text {Ara }}\right), 5.31-5.27$ (m, 4H, H-2 $\left.{ }^{\text {Ara }}, \mathrm{H}-2^{\text {Man }}, \mathrm{H}-3^{\text {Man }}, \mathrm{H}-4^{\text {Man }}\right), 5.14$ (m, 1H, H-3 $\left.{ }^{\text {Ara }}\right), 4.90$ (d, $J=$ $\left.1.0 \mathrm{~Hz}, 1 \mathrm{H}, \mathrm{H}-1^{\text {Man }}\right), 4.39$ (m, 1H, H-4 $\left.{ }^{\text {Ara }}\right), 4.02$ (m, 1H, H-5 $\left.{ }^{\text {Ara }}\right), 3.82$ (m, 1H, H-5'Ara) 4.30 (m, 1H, H-6 ${ }^{\text {Man }}$ ), 4.10 (m, 1H, H-6' Man $), 4.07$ (m, 1H, H-5 Man), 2.33 (s, 3H, Ac), 2.14 (s, 3H, Ac), 2.13 (s, 3H, Ac), 2.09 (s, 3H, Ac), 2.04 (s, 3H, Ac), 1.97 (s, 3H, Ac). $\left.{ }^{13} \mathrm{C} \mathrm{NMR} \mathrm{(100} \mathrm{MHz,} \mathrm{CDCl}\right) \delta$ 170.62, 170.15, 170.04, 169.89, 169.67, 169.63, 138.06, 132.84, 129.81, 129.46, 98.03 (C-1 $\left.{ }^{\mathrm{Man}}\right)$, $91.15\left(\mathrm{C}-1^{\text {Ara }}\right), 81.75,81.50,77.50,69.29,69.06,68.70,66.38,65.98,62.28,21.13,20.85,20.75$, 20.73, 20.70, 20.65, 20.63. $\mathrm{C}_{30} \mathrm{H}_{38} \mathrm{O}_{15} \mathrm{SNa}[\mathrm{M}+\mathrm{Na}]^{+}$, 693.1824; found, 693.1831.

\subsubsection{4-Methylphenyl}

$(2,3,5$-tri- $O$-acetyl- $\alpha$-D-arabinofuranosyl)-( $(1 \rightarrow 3)$-[2,3,5-tri- $O$-acetyl- $\alpha$-D-arabinofuranosyl-( $1 \rightarrow 5$ )]-2- $O$-acetyl-1-thio- $\alpha$-D-arabinofuranoside (15)

The dried compound $\mathbf{6}(100 \mathrm{mg}, 0.34 \mathrm{mmol}), 8(420 \mathrm{mg}, 1.00 \mathrm{mmol})$ and activated $4 \AA \mathrm{MS}(600$ $\mathrm{mg}$ ) were mixed together in anhydrous $\mathrm{CH}_{2} \mathrm{Cl}_{2}(5 \mathrm{~mL})$ stirred for $1 \mathrm{~h}$ at RT under argon. Then $\mathrm{BF}_{3} \cdot \mathrm{Et}_{2} \mathrm{O}(25 \mu \mathrm{L}, 0.17 \mathrm{mmol})$ was added and the reaction was left for $30 \mathrm{~min}$ at $-60{ }^{\circ} \mathrm{C}$ before quenching by triethylamine. After filtering by Celite and concentration, the resulting crude product was purified by column chromatography (cyclohexane: ethyl acetate $=1: 1)$ getting $15(110 \mathrm{mg}$, $40 \%)$ as colorless syrup. $\mathrm{R}_{\mathrm{f}}=0.3$ (cyclohexane: ethyl acetate $\left.=1: 1\right) . \quad[\alpha]_{\mathrm{D}}{ }^{25}+177.6\left(\mathrm{c} 0.6, \mathrm{CHCl}_{3}\right)$. ${ }^{1} \mathrm{H}$ NMR $\left(400 \mathrm{MHz}, \mathrm{CDCl}_{3}\right) \delta 7.40(\mathrm{~d}, J=8.1 \mathrm{~Hz}, \mathrm{Ph}), 7.11(\mathrm{~d}, J=8.1 \mathrm{~Hz}, \mathrm{Ph}), 5.47(\mathrm{~m}, 1 \mathrm{H}$, H-1 $\left.{ }^{\text {Ara-A }}\right), 5.27\left(\mathrm{~s}, 1 \mathrm{H}, \mathrm{H}-1^{\text {Ara-B }}\right), 5.21(\mathrm{t}, J=1.9 \mathrm{~Hz}, 1 \mathrm{H}), 5.15(\mathrm{~m}, 1 \mathrm{H}), 5.12\left(\mathrm{~m}, \mathrm{H}-1^{\text {Ara-B'}}\right), 5.12(\mathrm{~m}$, $1 \mathrm{H}), 5.01(\mathrm{~m}, 1 \mathrm{H}), 4.96(\mathrm{~m}, 1 \mathrm{H}), 4.44-4.35(\mathrm{~m}, 3 \mathrm{H}), 4.27-4.18(\mathrm{~m}, 5 \mathrm{H}), 3.92\left(\mathrm{dd}, J_{1}=4.3 \mathrm{~Hz}, J_{2}=\right.$ 
$11.6 \mathrm{~Hz}, 1 \mathrm{H}), 3.76\left(\mathrm{dd}, J_{1}=4.3 \mathrm{~Hz}, J_{2}=11.6 \mathrm{~Hz}, 1 \mathrm{H}\right), 2.99(\mathrm{~s}, 3 \mathrm{H}, \mathrm{Tol}), 2.12(\mathrm{~s}, 3 \mathrm{H}, \mathrm{Ac}), 2.12(\mathrm{~s}$, 3H, Ac), 2.10 (s, 3H, Ac), 2.09 (s, 3H, Ac), 2.09 (s, 3H, Ac), 2.08 (s, 3H, Ac), 2.08 (s, 3H, Ac). ${ }^{13} \mathrm{C}$ NMR $\left(100 \mathrm{MHz}, \mathrm{CDCl}_{3}\right) \delta 170.53,170.47,170.11,169.94,169.52,169.41,137.76,132.39$,

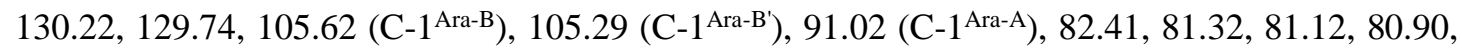
80.80, 80.68, 77.21, 76.86, 65.20, 63.21, 63.02, 21.11, 20.86, 20.75, 20.71, 20.63. HR ESI-TOF MS (m/z): calcd for $\mathrm{C}_{36} \mathrm{H}_{46} \mathrm{O}_{19} \mathrm{SNa}[\mathrm{M}+\mathrm{Na}]^{+}$, 837.2246; found 837.2216.

\subsubsection{4-Methylphenyl}

$(2,3,4,6$-tetra- $O$-acetyl- $\alpha$-D-mannopyranosyl)-( $1 \rightarrow 5)$-(2,3-di- $O$-acetyl- $\alpha$-D-arabinofuranosyl)-( $1 \rightarrow$ $3)$-[(2,3,4,6-tetra- $O$-acetyl- $\alpha$-D-mannopyranosyl)-( $1 \rightarrow 5)$-(2,3-di- $O$-acetyl- $\alpha$-D-arabinofuranosyl)$(1 \rightarrow 5)-]-2-O$-acetyl-1-thio- $\alpha$-D-arabinofuranoside (16)

To a solution of $\mathbf{1 1}(830 \mathrm{mg}, 1.24 \mathrm{mmol})$ in $16 \mathrm{~mL}$ wet $\mathrm{CH}_{2} \mathrm{Cl}_{2}\left(20 \% \mathrm{H}_{2} \mathrm{O}\right)$ was added NIS (558 $\mathrm{mg}, 2.48 \mathrm{mmol}), \operatorname{AgOTf}(318 \mathrm{mg}, 1.24 \mathrm{mmol})$ and TTBP $(744 \mathrm{mg}, 3 \mathrm{mmol})$. The solution was stirred for $1 \mathrm{~h}$ until no $\mathbf{1 1}$ left. The crude was purified by column chromatography (cyclohexane: ethyl acetate $=1: 2)$ to give $\mathbf{1 2}(629 \mathrm{mg}, 90 \%)$ as colorless syrup. All the $\mathbf{1 2}$ was immediately put into $6 \mathrm{~mL}$ dry $\mathrm{CH}_{2} \mathrm{Cl}_{2}$ under argon and then $\mathrm{CCl}_{3} \mathrm{CN}(1.1 \mathrm{~mL}, 11.1 \mathrm{mmol})$ and $\mathrm{DBU}(166 \mu \mathrm{L}, 1.11$ mmol) were added to the solution at ice bath. The solution was stirred for $1 \mathrm{~h}$ at $0{ }^{\circ} \mathrm{C}$ and solution was removed under vacuo and purified by column chromatography (cyclohexane: ethyl acetate $=$ 1:1) with $1 \%$ triethylamine added to afford $\mathbf{1 3}(705 \mathrm{mg}, 90 \%)$ as colorless syrup. $\mathbf{1 3}$ should be used without delay for its poor stability. The dried compound $\mathbf{6}$ (100 mg, $0.34 \mathrm{mmol}), \mathbf{1 3}$ (705 mg, $1.00 \mathrm{mmol})$ and activated $4 \AA \mathrm{MS}(1.5 \mathrm{~g})$ were mixed together in anhydrous $\mathrm{CH}_{2} \mathrm{Cl}_{2}(10 \mathrm{~mL})$ stirred for $1 \mathrm{~h}$ at $\mathrm{RT}$ under argon. Then $\mathrm{BF}_{3} \cdot \mathrm{Et}_{2} \mathrm{O}(25 \mu \mathrm{L}, 0.17 \mathrm{mmol})$ was added and the reaction was left for $30 \mathrm{~min}$ at $-60{ }^{\circ} \mathrm{C}$ before quenching by triethylamine. After filtering by Celite and concentration, the resulting crude product was purified by column chromatography (cyclohexane: ethyl acetate $=1: 2)$ getting $\mathbf{1 6}(172 \mathrm{mg}, 37 \%)$ as colorless syrup. $\mathrm{R}_{\mathrm{f}}=0.4$ (cyclohexane: ethyl acetate $=1: 2) .[\alpha]_{\mathrm{D}}{ }^{25}+84.5\left(\mathrm{c} 0.5, \mathrm{CHCl}_{3}\right) .{ }^{1} \mathrm{H} \mathrm{NMR}\left(400 \mathrm{MHz}, \mathrm{CDCl}_{3}\right) 7.42(\mathrm{~d}, J=8.1 \mathrm{~Hz}, 1 \mathrm{H}$, $\mathrm{Ph}), 7.12(\mathrm{~d}, J=8.1 \mathrm{~Hz}, 1 \mathrm{H}, \mathrm{Ph}), 5.48\left(\mathrm{~s}, 1 \mathrm{H}, \mathrm{H}-1^{\text {Ara-A }}\right), 5.33(\mathrm{~m}, 7 \mathrm{H}), 5.29\left(\mathrm{~s}, 1 \mathrm{H}, \mathrm{H}^{\text {Ara-B }}\right), 5.25$ $(\mathrm{t}, J=1.8 \mathrm{~Hz}, 1 \mathrm{H}), 5.19(\mathrm{~d}, J=1 \mathrm{~Hz}, 1 \mathrm{H}), 5.15-5.14(\mathrm{~m}, 2 \mathrm{H}), 5.13\left(\mathrm{~s}, 1 \mathrm{H}, \mathrm{H}-1^{\text {Ara-B' }}\right), 5.05$ (d, $J=$ $4.9 \mathrm{~Hz}, 1 \mathrm{H}), 4.92\left(\mathrm{~m}, 2 \mathrm{H}, \mathrm{H}-1^{\text {Man }}, \mathrm{H}-1^{\text {Man' }}\right), 4.46(\mathrm{~m}, 1 \mathrm{H}), 4.34-4.31(\mathrm{~m}, 2 \mathrm{H}), 4.23\left(\mathrm{dd}, J_{1}=1.4 \mathrm{~Hz}\right.$, $\left.J_{2}=5.6 \mathrm{~Hz}, 1 \mathrm{H}\right), 4.17-4.11(\mathrm{~m}, 6 \mathrm{H}), 4.04-4.01(\mathrm{~m}, 2 \mathrm{H}), 3.91-3.88(\mathrm{~m}, 1 \mathrm{H}), 3.81-3.75(\mathrm{~m}, 3 \mathrm{H})$, 2.34 (s, 3H, Tol), 2.17 (s, 6H, Ac), 2.17 (s, 3H, Ac), 2.14 (s, 3H, Ac), 2.13 (s, 3H, Ac), 2.13 (s, 3H, Ac), 2.12 (s, 6H, Ac), 2.10 (s, 3H, Ac), 2.06 (s, 3H, Ac), 2.06 (s, 3H, Ac), 1.99 (s, 3H, Ac), 1.98 (s, $3 \mathrm{H}, \mathrm{Ac}) .{ }^{13} \mathrm{C} \mathrm{NMR}\left(100 \mathrm{MHz}, \mathrm{CDCl}_{3}\right) \delta 170.64,170.37,170.28,170.12,169.99,169.91,169.89$, $169.70,169.64,169.61,137.68,132.37,130.37,129.72,105.46\left(\mathrm{C}-1^{\text {Ara-B }}\right), 105.21$ (C-1 $\left.{ }^{\text {Ara-B' }}\right)$, $98.14\left(\mathrm{C}-1^{\mathrm{Man}}\right), 98.12\left({\left.\mathrm{C}-1^{\text {Man'}}\right)}\right) 91.09\left(\mathrm{C}-1^{\text {Ara-A }}\right), 82.55,82.40,82.27,81.53,81.36,81.22,80.82$, $77.45,76.89,69.26,69.11,69.07,68.75,68.68,66.34,66.23,65.96,65.36,62.27,21.10,20.86$, 20.74, 20.71, 20.64, 20.62. HR ESI-TOF MS ( $/$ /z): calcd for $\mathrm{C}_{60} \mathrm{H}_{78} \mathrm{O}_{35} \mathrm{SNa}[\mathrm{M}+\mathrm{Na}]^{+}, 1413.3937$; found 1413.3970 .

4.2.8 4-Methylphenyl

$(2,3,4,6$-tetra- $O$-acetyl- $\alpha$-D-mannopyranosyl)-( $1 \rightarrow 3)$-[2,3,4,6-tetra- $O$-acetyl- $\alpha$-D-mannopyranosyl -(1 $\rightarrow 5)$-]-2- $O$-acetyl-1-thio- $\alpha$-D-arabinofuranoside (17) 
The dried compound $\mathbf{6}(100 \mathrm{mg}, 0.34 \mathrm{mmol}), \mathbf{1 0}(490 \mathrm{mg}, 1.00 \mathrm{mmol})$ and activated $4 \AA \mathrm{MS}(1 \mathrm{~g})$ were mixed together in anhydrous $\mathrm{CH}_{2} \mathrm{Cl}_{2}(7 \mathrm{~mL})$ stirred for $1 \mathrm{~h}$ at $\mathrm{RT}$ under argon. Then $\mathrm{BF}_{3} \cdot \mathrm{Et}_{2} \mathrm{O}(25 \mu \mathrm{L}, 0.17 \mathrm{mmol})$ was added and the reaction was left for $50 \mathrm{~min}$ at $-70{ }^{\circ} \mathrm{C}$ before quenching by triethylamine. After filtering by Celite and concentration, the resulting crude product was purified by column chromatography (cyclohexane : ethyl acetate $=2: 3)$ getting $17(172 \mathrm{mg}$, $32 \%)$ as colorless syrup. $\mathrm{R}_{\mathrm{f}}=0.4$ (cyclohexane: ethyl acetate $\left.=2: 3\right)$. $[\alpha]_{\mathrm{D}}^{25}+117.8\left(\mathrm{c} 0.5, \mathrm{CHCl}_{3}\right)$. ${ }^{1} \mathrm{H}$ NMR (400 MHz, $\left.\mathrm{CDCl}_{3}\right) \delta 5.45$ (s, 1H, H-1 $\left.{ }^{\text {Ara }}\right), 5.37-5.25(\mathrm{~m}, 6 \mathrm{H}), 5.18(\mathrm{~s}, 1 \mathrm{H}), 5.09$ (d, $J=$ $\left.1.6 \mathrm{~Hz}, 1 \mathrm{H}, \mathrm{H}-1^{\text {Man }}\right), 4.94\left(\mathrm{~d}, J=1.0 \mathrm{~Hz}, 1 \mathrm{H}, \mathrm{H}-1^{\text {Man' }}\right), 4.53-4.52(\mathrm{~m}, 1 \mathrm{H}), 4.32-4.23(\mathrm{~m}, 3 \mathrm{H})$, 4.20-4.19 (m, 1H), 4.13-4.05 (m, 2H ), 4.04-3.99 (m, 2H), 3.87 (t, $J=3.9 \mathrm{~Hz}, 1 \mathrm{H}), 2.32$ (s, 3H, Tol), 2.17 (s, 3H, Ac), 2.13 (s, 3H, Ac), 2.10 (s, 3H, Ac), 2.08 (s, 3H, Ac), 2.08 (s, 3H, Ac), 2.05 (s, $3 \mathrm{H}, \mathrm{Ac}), 2.04$ (s, 3H, Ac), 2.00 (s, 3H, Ac), 1.96 (s, 3H, Ac). ${ }^{13} \mathrm{C}$ NMR $\left(100 \mathrm{MHz}, \mathrm{CDCl}_{3}\right) \delta$ 170.55, 170.40, 170.03, 169.86, 169.77, 169.74, 169.70, 169.62, 138.03, 132.91, 129.81, 129.63, 98.10 (C-1 $\left.^{\text {Man }}\right), 97.48$ (C-1 $\left.{ }^{\text {Man'}}\right), 91.06$ (C-1 $\left.{ }^{\text {Ara }}\right), 82.34,82.19,81.53,69.40,69.32,69.13,68.93$, $68.74,68.65,66.24,65.98,62.59,62.32,21.13,20.84,20.68,20.65,20.60$. HR ESI-TOF MS $(\mathrm{m} / \mathrm{z})$ : calcd for $\mathrm{C}_{42} \mathrm{H}_{54} \mathrm{O}_{23} \mathrm{SNa}[\mathrm{M}+\mathrm{Na}]^{+}, 981.2669$; found 981.2682.

\subsubsection{Cyanomethyl}

$(2,3,5$-tri- $O$-acetyl- $\alpha$-D-arabinofuranosyl)-( $1 \rightarrow 3)$-[2,3,5-tri- $O$-acetyl- $\alpha$-D-arabinofuranosyl-( $1 \rightarrow 5)$ ]-(2- $O$-acetyl- $\alpha$-D-arabinofuranosyl)-( $1 \rightarrow 6)-2,3,4$-tri- $O$-acetyl-1-thio- $\alpha$-D-mannopyranoside (18)

The dried 15 (40 mg, $0.049 \mathrm{mmol}), 14(27 \mathrm{mg}, 0.073 \mathrm{mmol})$ and activated $4 \AA \mathrm{MS}$ (100 mg) were mixed together in anhydrous $\mathrm{CH}_{2} \mathrm{Cl}_{2}(2 \mathrm{~mL})$ for $1 \mathrm{~h}$ at $\mathrm{RT}$. The reaction was put at $-30{ }^{\circ} \mathrm{C}$ for 5 min before NIS (13 mg, $0.059 \mathrm{mmol})$ and AgOTf $(15 \mathrm{mg}, 0.059 \mathrm{mmol})$ were added. Upon for stirring at $-30{ }^{\circ} \mathrm{C}$ for $50 \mathrm{~min}$, the reaction was diluted with $\mathrm{CH}_{2} \mathrm{Cl}_{2}$, after filtering by Celite, the organic phase was washed with saturated aq. $\mathrm{Na}_{2} \mathrm{~S}_{2} \mathrm{O}_{3}$, water and dried over $\mathrm{MgSO}_{4}$, and then concentrated under reduced pressure. The residue was finally purified by silica gel column chromatography with cyclohexane: ethyl acetate (1:2) as the eluent to afford $\mathbf{1 8}(31 \mathrm{mg}, 60 \%)$ as foamy solid. $\mathrm{R}_{\mathrm{f}}=0.3$ (cyclohexane: ethyl acetate $\left.=1: 2\right) .[\alpha]_{\mathrm{D}}{ }^{25}+196.0\left(\mathrm{c} 0.5, \mathrm{CHCl}_{3}\right) .{ }^{1} \mathrm{H}$ NMR $\left(400 \mathrm{MHz}, \mathrm{CDCl}_{3}\right) \delta 5.47\left(\mathrm{~s}, 1 \mathrm{H}, \mathrm{H}-1^{\mathrm{Man}}\right), 5.37(\mathrm{~m}, 1 \mathrm{H}), 5.23\left(\mathrm{~m}, 1 \mathrm{H}, \mathrm{H}-1^{\text {Ara-B }}\right), 5.22-5.20(\mathrm{~m}, 2 \mathrm{H})$ $5.14\left(\mathrm{~m}, 1 \mathrm{H}, \mathrm{H}^{\text {Ara-B' }}\right)$, 5.14-5.10 $(\mathrm{m}, 2 \mathrm{H}), 5.05-5.03(\mathrm{~m}, 1 \mathrm{H}), 4.98\left(\mathrm{~m}, 1 \mathrm{H}, \mathrm{H}-1^{\text {Ara-A }}\right), 4.98-4.95$ $(\mathrm{m}, 2 \mathrm{H}), 4.46-4.42(\mathrm{~m}, 2 \mathrm{H}), 4.29-4.18(\mathrm{~m}, 7 \mathrm{H}), 3.91-3.85(\mathrm{~m}, 2 \mathrm{H}), 3.74\left(\mathrm{dd}, J_{1}=2.3 \mathrm{~Hz}, J_{2}=11.6\right.$ $\mathrm{Hz}, 1 \mathrm{H}), 3.57\left(\mathrm{~d}, J=17.3 \mathrm{~Hz}, \mathrm{SCH}_{2} \mathrm{CH}\right), 3.50\left(\mathrm{dd}, J_{1}=2.3 \mathrm{~Hz}, J_{2}=11.6 \mathrm{~Hz}, 1 \mathrm{H}\right), 3.36(\mathrm{~d}, J=$ $17.3 \mathrm{~Hz}, \mathrm{SCH}_{2} \mathrm{CH}$ ), 2.17 (s, 3H, Ac), 2.12 (s, 3H, Ac), 2.10 (s, 18H, Ac), 2.06 (s, 3H, Ac), 1.99 (s, $3 \mathrm{H}, \mathrm{Ac}) .{ }^{13} \mathrm{C}$ NMR $\left(100 \mathrm{MHz}, \mathrm{CDCl}_{3}\right) \delta 170.55,170.45,170.23,170.13,170.11,169.83,169.71$, 169.65, 169.39, 115.98, $105.73\left(\mathrm{C}-1^{\text {Ara-B }}\right), 105.52\left(\mathrm{C}-1^{\text {Ara-B'}}\right), 104.74\left(\mathrm{C}-1^{\text {Ara-A }}\right), 82.13,81.45$, 81.28, 80.81 (C-1 $\left.{ }^{\mathrm{Man}}\right), 80.78,80.58,80.14,79.60,70.49,69.47,66.53,65.56,65.13,63.23,62.73$, 20.85, 20.73, 20.69, 20.63, 20.54, 14.77. HR ESI-TOF MS $(\mathrm{m} / \mathrm{z})$ : calcd for $\mathrm{C}_{43} \mathrm{H}_{57} \mathrm{NO}_{27} \mathrm{SNa}$ $[\mathrm{M}+\mathrm{Na}]^{+}, 1074.2731$; found 1074.2735 .

\subsubsection{Cyanomethyl}

$(2,3,4,6$-tetra- $O$-acetyl- $\alpha$-D-mannopyranosyl)-( $1 \rightarrow 5)$-(2,3-di- $O$-acetyl- $\alpha$-D-arabinofuranosyl)-( $1 \rightarrow$ $3)$-[(2,3,4,6-tetra- $O$-acetyl- $\alpha$-D-mannopyranosyl)-( $1 \rightarrow 5)$-(2,3-di- $O$-acetyl- $\alpha$-D-arabinofuranosyl)$(1 \rightarrow 3)$-]-(2- $O$-acetyl- $\alpha$-D-arabinofuranosyl)-( $(1 \rightarrow 6)-2,3,4$-tri- $O$-acetyl-1-thio- $\alpha$-D-mannopyranosid 
The dried 16 (45 mg, $0.032 \mathrm{mmol}), \mathbf{1 4}$ (18 mg, $0.049 \mathrm{mmol})$ and activated $4 \AA \mathrm{MS}$ (100 mg) were mixed together in anhydrous $\mathrm{CH}_{2} \mathrm{Cl}_{2}(2 \mathrm{~mL})$ for $1 \mathrm{~h}$ at $\mathrm{RT}$. The reaction was put at $-30{ }^{\circ} \mathrm{C}$ for 5 min before NIS $(8.5 \mathrm{mg}, 0.038 \mathrm{mmol})$ and AgOTf $(10 \mathrm{mg}, 0.038 \mathrm{mmol})$ were added. Upon for stirring at $-30{ }^{\circ} \mathrm{C}$ for $50 \mathrm{~min}$, the reaction was diluted with $\mathrm{CH}_{2} \mathrm{Cl}_{2}$, after filtering by Celite, the organic phase was washed with saturated aq. $\mathrm{Na}_{2} \mathrm{~S}_{2} \mathrm{O}_{3}$, water and dried over $\mathrm{MgSO}_{4}$, and then concentrated under reduced pressure. The residue was finally purified by silica gel column chromatography with cyclohexane: ethyl acetate (1:3) as the eluent to afford $\mathbf{1 8}(26 \mathrm{mg}, 49 \%)$ as foamy solid. $\mathrm{R}_{\mathrm{f}}=0.25$ (cyclohexane: ethyl acetate $\left.=1: 3\right) \cdot[\alpha]_{\mathrm{D}}{ }^{25}+70.4\left(\mathrm{c} 0.5, \mathrm{CHCl}_{3}\right) .{ }^{1} \mathrm{H} \mathrm{NMR}$ $\left(400 \mathrm{MHz}, \mathrm{CDCl}_{3}\right) \delta 5.45\left(\mathrm{~s}, 1 \mathrm{H}, \mathrm{H}-1^{\text {Man-A }}\right), 5.35(\mathrm{~m}, 1 \mathrm{H}), 5.28(\mathrm{~m}, 6 \mathrm{H}), 5.21\left(\mathrm{~m}, 1 \mathrm{H}, \mathrm{H}-1^{\text {Ara-A }}\right)$, 5,21-5.17 (m, 2H), 5.15-5.10 (m, 3H), 5.00-4.97 (m, 2H), $5.10\left(\mathrm{~m}, 1 \mathrm{H}, \mathrm{H}-1^{\text {Ara-B }}\right), 4.97(\mathrm{~m}, 1 \mathrm{H}$, $\left.\mathrm{H}^{-1}{ }^{\text {Ara-B'}}\right), 4.89$ (m, 2H, H-1 $\left.{ }^{\text {Man-B }}, \mathrm{H}-1^{\text {Man-B'}}\right), 4.31-4.23(\mathrm{~m}, 3 \mathrm{H}), 4.18(\mathrm{~m}, 2 \mathrm{H}), 4.13-4.07(\mathrm{~m}, 6 \mathrm{H})$, 4.02-3.96 (m, 2H), 3.89-3.77 (m, 3H), 3.72-3.68 (m, 2H), $3.58(\mathrm{~d}, J=17 \mathrm{~Hz}, 1 \mathrm{H}), 3.50(\mathrm{~m}, 1 \mathrm{H})$, 3.36 (d, $J=17 \mathrm{~Hz}, 1 \mathrm{H}$ ), 2.15 (s, 3H, Ac), 2.13 (s, 9H, Ac), 2.10 (s, 3H, Ac), 2.08 (s, 15H, Ac), 2.04 (s, 3H, Ac), 2.02 (s, 6H, Ac), 1.96 (s, 3H, Ac), 1.95 (s, 3H, Ac), 1.94 (s, 3H, Ac). ${ }^{13} \mathrm{C}$ NMR $\left(100 \mathrm{MHz}, \mathrm{CDCl}_{3}\right) \delta 170.60,170.39,170.33,170.06,169.90,169.88,169.85,169.66,169.62$,

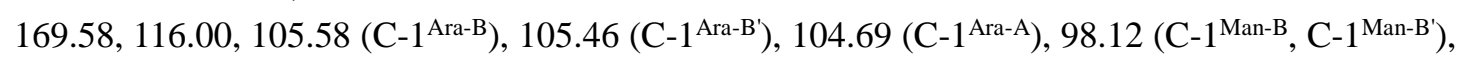
$82.42,82.04,81.94,81.75,81.22,81.07,80.50\left(\mathrm{C}-1^{\text {Man-A }}\right), 79.75,77.53,70.53,69.47,69.22$, $69.10,69.06,68.74,68.67,66.51,66.44,66.08,65.92,65.66,65.21,62.24,20.84,20.71,20.69$, 20.60, 20.53, 14.77. HR ESI-TOF MS (m/z): calcd for $\mathrm{C}_{67} \mathrm{H}_{89} \mathrm{NO}_{43} \mathrm{SNH}_{4}\left[\mathrm{M}+\mathrm{NH}_{4}\right]^{+}, 1645.4867$; found 1645.4871 .

\subsubsection{Cyanomethyl}

$(2,3,4,6$-tetra- $O$-acetyl- $\alpha$-D-mannopyranosyl)-( $1 \rightarrow 3)$-[2,3,4,6-tetra- $O$-acetyl- $\alpha$-D-mannopyranosyl -(1 $\rightarrow 5)$-]-(2-O-acetyl- $\alpha$-D-arabinofuranosyl)-( $(1 \rightarrow 6)-2,3,4$-tri- $O$-acetyl-1-thio- $\alpha$-D-mannopyranosid e (20)

The dried 17 (40 mg, $0.041 \mathrm{mmol}), \mathbf{1 4}(22 \mathrm{mg}, 0.061 \mathrm{mmol})$ and activated $4 \AA \mathrm{MS}(100 \mathrm{mg})$ were mixed together in anhydrous $\mathrm{CH}_{2} \mathrm{Cl}_{2}(2 \mathrm{~mL})$ for $1 \mathrm{~h}$ at $\mathrm{RT}$. The reaction was put at $-30{ }^{\circ} \mathrm{C}$ for 5 min before NIS (11 mg, $0.049 \mathrm{mmol})$ and AgOTf (12.5 mg, $0.049 \mathrm{mmol})$ were added. Upon for stirring at $-30{ }^{\circ} \mathrm{C}$ for $50 \mathrm{~min}$, the reaction was diluted with $\mathrm{CH}_{2} \mathrm{Cl}_{2}$, after filtering by Celite, the organic phase was washed with saturated aq. $\mathrm{Na}_{2} \mathrm{~S}_{2} \mathrm{O}_{3}$, water and dried over $\mathrm{MgSO}_{4}$, and then concentrated under reduced pressure. The residue was finally purified by silica gel column chromatography with cyclohexane: ethyl acetate (1:2) as the eluent to afford $\mathbf{1 8}(27 \mathrm{mg}, 55 \%)$ as foamy solid. $\mathrm{R}_{\mathrm{f}}=0.3$ (cyclohexane: ethyl acetate $\left.=1: 2\right)$. $[\alpha]_{\mathrm{D}}{ }^{25}+129.7\left(\mathrm{c} 0.5, \mathrm{CHCl}_{3}\right) .{ }^{1} \mathrm{H} \mathrm{NMR}$ $\left(400 \mathrm{MHz}, \mathrm{CDCl}_{3}\right) \delta 5.46\left(\mathrm{~m}, \mathrm{H}-1^{\text {Man-A}}\right), 5.39\left(\mathrm{dd}, J_{1}=1.3 \mathrm{~Hz}, J_{2}=3.2 \mathrm{~Hz}, 1 \mathrm{H}\right), 5.33-5.27(\mathrm{~m}$, $6 \mathrm{H}), 5.24-5.17(\mathrm{~m}, 3 \mathrm{H}), 5.10\left(\mathrm{~m}, \mathrm{H}-1^{\text {Man-B}}\right), 5.00(\mathrm{~m}, 1 \mathrm{H}), 4.99-4.98\left(\mathrm{~m}, 2 \mathrm{H}, \mathrm{H}-1^{\text {Man-B' }}, \mathrm{H}^{-1}{ }^{\text {Ara }}\right)$, 4.35-4.21 (m, 5H), 4.14-4.06 (m, 2H), 4.03-3.82 (m, 5H), 3.60-3.54 (m, 2H), 3.49 (d, $J=17 \mathrm{~Hz}$, 1H), 2.18 (s, 3H, Ac), 2.16 (s, 3H, Ac), 2.15 (s, 3H, Ac), 2.11 (s, 3H, Ac), 2.10 (s, 3H, Ac), 2.10 (s, 3H, Ac), 2.07 (s, 3H, Ac), 2.05 (s, 3H, Ac), 2.04 (s, 3H, Ac), 1.99 (m, 6H, Ac), 1.96 (s, 3H, Ac). ${ }^{13} \mathrm{C}$ NMR $\left(100 \mathrm{MHz}, \mathrm{CDCl}_{3}\right) \delta 170.56,170.40,170.23,170.03,169.87,169.85,169.80,169.71$,

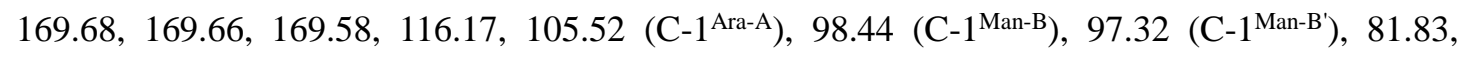
81.70, 81.56, 80.73 (C-1 $\left.1^{\text {Man-A }}\right), 70.47,69.40,69.37,69.15,69.02,68.93,68.80,66.54,66.17$, 
$66.03,65.79,65.66,62.49,62.41,20.85,20.81,20.75,20.70,20.66,20.63,20.60,20.58,20.53$,

14.85. HR ESI-TOF MS $(\mathrm{m} / \mathrm{z})$ : calcd for $\mathrm{C}_{67} \mathrm{H}_{89} \mathrm{NO}_{43} \mathrm{SNH}_{4}\left[\mathrm{M}+\mathrm{NH}_{4}\right]^{+}, 1213.3599$; found 1213.3605 .

\subsection{Preparation of neo-glycoproteins}

Compounds 18-20 (0.005-0.01 mmol) were dissolved in $3 \mathrm{~mL}$ of dry methanol and $1 \mathrm{wt} \%$ of sodium methoxide $(0.18 \mathrm{mmol})$ was added. The reaction was reacted for $48 \mathrm{~h}$ under nitrogen at $35^{\circ} \mathrm{C}$, after which time the reaction mixture was concentrated in vacuo and the solid formed was characterized by ESI-MS analysis (See Figures S1-S3 in the additional information). The MS analysis were carried out on a LTQ-MS (Thermo Electron, San Jose, CA) with an electrospray ionization (ESI) source controlled by X-calibur software 1.4 (Thermo Finnigan, San Jose, CA). The samples were dissolved in methanol and introduced into the mass spectrometer with a syringe pump at a flow rate of $10 \mu \mathrm{L} / \mathrm{min}$. Full scan MS experiments were carried out under the following instrumental conditions: positive ion mode, mass range 300-1500 m/z, source voltage $4.6 \mathrm{kV}$, capillary voltage $36 \mathrm{~V}$, sheath gas 6 , auxiliary gas 1 , capillary temperature $250{ }^{\circ} \mathrm{C}$, tube lens voltage $80 \mathrm{~V}$.

rHSA derived from gene-modified rice endosperm, was selected as carrier protein in order to have a pure ( $>99 \%$ by SDS-PAGE) homogeneous and non-antigenic protein. The reaction solutions were analysed by Hydrophilic Interaction Liquid Chromatography (HILIC) using an UV detector. Thus, an aliquot of $10 \mu \mathrm{L}$ of each reaction mixture was brought to $\mathrm{pH} 6$ by adding $1 \mathrm{M}$ $\mathrm{HCl}(2.3 \mu \mathrm{L})$, diluted with water to reach a final concentration of $0.5 \mathrm{mg} / \mathrm{mL}$ and directly injected in the chromatographic system. Chromatographic separations were performed on an Agilent HPLC series 1100 system, equipped with mobile-phase online degasser, quaternary pump, autosampler, column thermostated compartment, and diode array detector. For data acquisition and analysis, the ChemStation software version Rev. B.04.01 was used in a Microsoft Windows XP environment.

The chromatographic conditions were optimized starting from an already reported method[29]. The selected HILIC column was an AdvanceBio Glycan Mapping column $(150 \times 2.1 \mathrm{~mm}, 2.7 \mu \mathrm{m})$ from Agilent Technologies (Palo Alto, CA, USA). The mobile phase was composed of ACN and water both containing $0.1 \%$ TFA. The elution gradient was from $28 \%$ to $51 \%$ B in $35 \mathrm{~min}$. The injection volume was fixed at $5 \mu \mathrm{L}$, the column temperature at $60{ }^{\circ} \mathrm{C}$ and the flow rate was set at $0.25 \mathrm{~mL} / \mathrm{min}$. According to the results obtained in the optimization study, the final glycosylation method entails a rHSA concentration of $2.0 \mathrm{mg} / \mathrm{mL}$, a glycoside/protein molar ratio of 200/1 and the use of sodium tetraborate buffer $(100 \mathrm{mM}, \mathrm{pH}$ 9.5). Thus, rHSA was dissolved in the buffer and the resulting solution was mixed with IME-glycoside. The reaction mixture was vortexed for $1 \mathrm{~min}$ and incubated for $24 \mathrm{~h}$ at $25^{\circ} \mathrm{C}$ under continuous stirring. At the end of the reaction, the samples were purified by ultrafiltration in order to remove reagents and salts (seven 10 min steps of centrifugation at $13000 \mathrm{~g}$ and $4{ }^{\circ} \mathrm{C}$ ) using centrifuge 5804-R (Eppendorf s.r.l., Milan, Italy) and Millipore's Amicon ${ }^{\circledR}$ Ultra filters with a nominal molecular weight limit of $10 \mathrm{kDa}$ and load capacity of $500 \mu \mathrm{L}$. HSA conjugates were finally collected in water and lyophilized. MALDI-ToF MS analysis was performed for the characterization of the different neo-glycoproteins (see Figure S5). 
The experiments were performed on an Autoflex III instrument (Bruker Daltonics, Inc., Bremen, Germany), equipped with a SmartBeam Nd:YAG laser emitting at $355 \mathrm{~nm}$. Each mass spectrum represents an accumulation of 3000 laser shots obtained in the linear mode, with a repetition rate of $100 \mathrm{~Hz}$, using DHB as the matrix. Calibration was performed using ProMix 3 (LaserBio Labs, Valbonne, FR).

Based upon the mass difference between the peak summit for the un-conjugated rHSA and each of the 3 conjugated saccharides, using the molecular weight of the different IME-oligosaccharide, it was estimated the average level of conjugation (average number of oligosaccharides attached): 21 (ManAra3-rHSA) 14.24; 22 (Man3Ara3-rHSA) 12.21; 23 (Man3Ara) 14.22.

\subsection{Biological ex-vivo Immunological evaluation}

4.4.1 Studied population: The population considered in the study included 30 subjects with newly diagnosed and untreated active pulmonary TB, as well as 16 healthy individuals without any history of TB exposure (hereafter indicated as TB unexposed controls). The diagnosis of active TB was confirmed by $M$. tuberculosis culture isolation in all cases. A detailed analysis of the main demographic features of each study group are shown in the Supplementary information (Table S5).

4.4.2 ELISA assay: Antibodies directed against neo-glycoproteins were determined as previously described by ELISA assay with minor modifications[32]. ELISA assay was performed in 96-well microtiter plates (Nunc Maxisorp, Invitrogen, Italy) coated with rHSA, 21, 22 and 23 (1 microg/well) diluted in $100 \mu \mathrm{L}$ of carbonate buffer $(\mathrm{pH}=9.6)$ and incubated $1 \mathrm{~h}$ at $\mathrm{RT}$ and overnight at $4{ }^{\circ} \mathrm{C}$. The wells were then washed (2 times with $200 \mu \mathrm{L}$ phosphate-buffered saline (PBS) containing $0.05 \%$ Tween-20 (PBS-T). The plate was incubated (RT, $1 \mathrm{~h}$ ) with $100 \mathrm{~mL}$ of serum (1:100). Plates were incubated $1 \mathrm{~h}$ at RT with anti-human IgG Secondary Antibody HRP conjugated (Invitrogen, Italy). All samples were measured in duplicate and for each serum, difference in mean ODs of antigen- and buffer-coated wells was calculated.

4.4.3 Statistical analysis and cut off determination: Data was reported as the mean values \pm standard deviation (SD). Comparisons between two groups were performed by Student's t-test. $p$ values $<0.05$ were considered to be statistically significant. GraphPad Prism version 5.0 (GraphPad Software, Inc., La Jolla, CA) was used for all statistical analyses and graphs. By utilizing the formula (Average of negative controls + (3 X Standard deviation of negative controls)), the cut of value was set for each protein/glycoprotein.

4.4.4 Ethics statement: The Ethics Committee of the University of Rome "Tor Vergata" (Rome, Italy) approved the study protocol (protocol number 173/19).

\section{Acknowledgements}

We thank the China Scholarship Council (CSC) for Ph.D. fellowships to Zhihao Li and Changping Zheng. Financial supports from the Centre National de la Recherche Scientifique (CNRS) and the Sorbonne Université in France are gratefully acknowledged. We also thank Linyan Wang, the 
account Manager of Healthgen Biotechnology Corp (Wuhan, China) for the technical assistance in the use of rHSA.

\section{References}

[1] Global tuberculosis report 2019, 2019. https://www.who.int/tb/publications/global_report/en/.

[2] N.R. Gandhi, P. Nunn, K. Dheda, H.S. Schaaf, M. Zignol, D. Van Soolingen, P. Jensen, J. Bayona, Multidrug-resistant and extensively drug-resistant tuberculosis: a threat to global control of tuberculosis, The Lancet, 375 (2010) 1830-1843.

[3] H. McShane, Tuberculosis vaccines: beyond bacille Calmette-Guérin, Philosophical Transactions of the Royal Society B: Biological Sciences, 366 (2011) 2782-2789.

[4] R.D. Astronomo, D.R. Burton, Carbohydrate vaccines: developing sweet solutions to sticky situations?, Nature Reviews Drug Discovery, 9 (2010) 308-324.

[5] M. Tontini, F. Berti, M. Romano, D. Proietti, C. Zambonelli, M. Bottomley, E. De Gregorio, G. Del Giudice, R. Rappuoli, P. Costantino, Comparison of CRM197, diphtheria toxoid and tetanus toxoid as protein carriers for meningococcal glycoconjugate vaccines, Vaccine, 31 (2013) 4827-4833.

[6] R. Adamo, A. Nilo, B. Castagner, O. Boutureira, F. Berti, G.J. Bernardes, Synthetically defined glycoprotein vaccines: current status and future directions, Chemical Science, 4 (2013) 2995-3008.

[7] P. Stallforth, B. Lepenies, A. Adibekian, P.H. Seeberger, Carbohydrates: a frontier in medicinal chemistry, Journal of Medicinal Chemistry, 52 (2009) 5561-5577.

[8] O. Finco, R. Rappuoli, Designing vaccines for the twenty-first century society, Frontiers in Immunology, 5 (2014) 12.

[9] T.L. Lowary, Twenty years of mycobacterial glycans: furanosides and beyond, Accounts of Chemical Research, 49 (2016) 1379-1388.

[10] A.K. Mishra, N.N. Driessen, B.J. Appelmelk, G.S. Besra, Lipoarabinomannan and related glycoconjugates: structure, biogenesis and role in Mycobacterium tuberculosis physiology and host-pathogen interaction, FEMS Microbiology Reviews, 35 (2011) 1126-1157.

[11] M. Jankute, S. Grover, H.L. Birch, G.S. Besra, Genetics of mycobacterial arabinogalactan and lipoarabinomannan assembly, Molecular Genetics of Mycobacteria, (2014) 535-557.

[12] A. Viljoen, M. Richard, P.C. Nguyen, P. Fourquet, L. Camoin, R.R. Paudal, G.R. Gnawali, C.D. Spilling, J.-F. Cavalier, S. Canaan, Cyclipostins and cyclophostin analogs inhibit the antigen $85 \mathrm{C}$ from Mycobacterium tuberculosis both in vitro and in vivo, Journal of Biological Chemistry, 293 (2018) 2755-2769.

[13] G. Källenius, A. Pawlowski, B. Hamasur, S.B. Svenson, Mycobacterial glycoconjugates as vaccine candidates against tuberculosis, Trends in Microbiology, 16 (2008) 456-462.

[14] Z. Li, C. Zheng, M. Terreni, L. Tanzi, M. Sollogoub, Y. Zhang, Novel vaccine candidates against tuberculosis, Current Medicinal Chemistry, (2020). doi: 10.2174/0929867326666181126112124.

[15] Z. Li, C. Zheng, M. Terreni, T. Bavaro, M. Sollogoub, Y. Zhang, A Concise Synthesis of Oligosaccharides Derived From Lipoarabinomannan (LAM) with Glycosyl Donors Having a Nonparticipating Group at C2, European Journal of Organic Chemistry, 14 (2020) 2033-2044.

[16] L. Wang, S. Feng, L. An, G. Gu, Z. Guo, Synthetic and immunological studies of mycobacterial lipoarabinomannan oligosaccharides and their protein conjugates, The Journal of Organic Chemistry, 80 (2015) 10060-10075. 
[17] T. Bavaro, M. Filice, C. Temporini, S. Tengattini, I. Serra, C. Morelli, G. Massolini, M. Terreni, Chemoenzymatic synthesis of neoglycoproteins driven by the assessment of protein surface reactivity, RSC Advances, 4 (2014) 56455-56465.

[18] A. Dunne, J.M. Palomo, Efficient and green approach for the complete deprotection of O-acetylated biomolecules, RSC Advances, 6 (2016) 88974-88978.

[19] M. Filice, J.M. Guisan, M. Terreni, J.M. Palomo, Regioselective monodeprotection of peracetylated carbohydrates, Nature Protocols, 7 (2012) 1783.

[20] J.C. Pastre, D.L. Browne, S.V. Ley, Flow chemistry syntheses of natural products, Chemical Society Reviews, 42 (2013) 8849-8869.

[21] R. Yuryev, S. Strompen, A. Liese, Coupled chemo (enzymatic) reactions in continuous flow, Beilstein Journal of Organic Chemistry, 7 (2011) 1449-1467.

[22] P. Costantino, R. Rappuoli, F. Berti, The design of semi-synthetic and synthetic glycoconjugate vaccines, Expert Opinion on Drug Discovery, 6 (2011) 1045-1066.

[23] C. Temporini, T. Bavaro, S. Tengattini, I. Serra, G. Marrubini, E. Calleri, F. Fasanella, L. Piubelli, F. Marinelli, L. Pollegioni, G. Speranza, G. Massolini and M. Terreni. Liquid chromatography-mass spectrometry structural characterization of neo glycoproteins aiding the rational design and synthesis of a novel glycovaccine for protection against tuberculosis, Journal of Chromatography A, 1367 (2014) 57-67.

[24] T. Bavaro, S. Tengattini, L. Piubelli, F. Mangione, R. Bernardini, V. Monzillo, S. Calarota, P. Marone, M. Amicosante, L. Pollegioni, C. Temporini and M. Terreni. Glycosylation of recombinant antigenic proteins from Mycobacterium tuberculosis: in silico prediction of protein epitopes and ex vivo biological evaluation of new semi-synthetic glycoconjugates, Molecules, 22 (2017) 1081.

[25] S.J. Jun, M.S. Moon, S.H. Lee, C.S. Cheong, K.S. Kim, Selective monodeacetylation of methyl 2, 3, 5-tri-O-acetyl-D-arabinofuranoside using biocatalyst, Tetrahedron Letters, 46 (2005) 5063-5065.

[26] T. Bavaro, A. Pinto, F. Dall’Oglio, M.J. Hernáiz, C.F. Morelli, P. Zambelli, C. De Micheli, P. Conti, L. Tamborini, M. Terreni, Flow-based biocatalysis: Application to peracetylated arabinofuranosyl-1, 5-arabinofuranose synthesis, Process Biochemistry, 72 (2018) 112-118.

[27] M.K. Gurjar, L.K. Reddy, S. Hotha, Synthesis of Oligosaccharides of Motifs D and E of Arabinogalactan Present in Mycobacterium t uberculosis, The Journal of Organic Chemistry, 66 (2001) 4657-4660.

[28] M. Tosin, P.V. Murphy, Synthesis of structurally defined scaffolds for bivalent ligand display based on glucuronic acid anilides. The degree of tertiary amide isomerism and folding depends on the configuration of a glycosyl azide, The Journal of Organic Chemistry, 70 (2005) 4107-4117.

[29] S. Tengattini, E. Domínguez-Vega, C. Temporini, T. Bavaro, F. Rinaldi, L. Piubelli, L. Pollegioni, G. Massolini, G.W. Somsen, Hydrophilic interaction liquid chromatography-mass spectrometry as a new tool for the characterization of intact semi-synthetic glycoproteins, Analytica Chimica Acta, 981 (2017) 94-105.

[30] Y. Chang, X. Meng, Y. Li, J. Liang, T. Li, D. Meng, T. Zhu, P. Yu, Synthesis and immunogenicity of the Mycobacterium tuberculosis arabinomannan-CRM197 conjugate, MedChemComm, 10 (2019) 543-553.

[31] L. Wang, S. Feng, S. Wang, H. Li, Z. Guo, G. Gu, Synthesis and Immunological Comparison of Differently Linked Lipoarabinomannan Oligosaccharide - Monophosphoryl Lipid A Conjugates as Antituberculosis Vaccines, The Journal of Organic Chemistry, 82 (2017) 12085-12096.

[32] R. Bernardini, R. Aufieri, A. Detcheva, S. Recchia, R. Cicconi, M. Amicosante, C. Montesano, P. 
Rossi, H.K. Tchidjou, B. Petrunov, Neonatal protection and preterm birth reduction following maternal group B streptococcus vaccination in a mouse model, The Journal of Maternal-Fetal \& Neonatal Medicine, 30 (2017) 2844-2850. 